\title{
Salt Stress Enhances Early Symbiotic Gene Expression in Medicago truncatula and Induces a Stress-Specific Set of Rhizobium-Responsive Genes
}

\author{
Sanhita Chakraborty, ${ }^{1,2}$ Heather E. Driscoll, ${ }^{3}$ Juan E. Abrahante, ${ }^{4}$ Fan Zhang, ${ }^{5,6}$ Robert F. Fisher, ${ }^{7}$ and \\ Jeanne M. Harris ${ }^{1, \dagger}$ \\ ${ }^{1}$ Department of Plant Biology, University of Vermont, Burlington, VT 05405, U.S.A. \\ ${ }^{2}$ Department of Bacteriology, University of Wisconsin-Madison, Madison, WI 53706, U.S.A. \\ ${ }^{3}$ Vermont Biomedical Research Network (VBRN), Department of Biology, Norwich University, Northfield, VT 05663, U.S.A. \\ ${ }^{4}$ University of Minnesota Informatics Institute (UMII) (CCRB 1-210C), Minneapolis, MN 55455, U.S.A. \\ ${ }^{5}$ VBRN, Department of Biology, University of Vermont, Burlington, VT 05405, U.S.A. \\ ${ }^{6}$ Institute for Translational Research and Department of Family Medicine, University of North Texas Health Science Center, Fort \\ Worth, TX, 76107, U.S.A. \\ ${ }^{7}$ Stanford University, Department of Biology, Stanford, CA 94305-5020, U.S.A.
}

Accepted 4 April 2021.

Salt stress is a major agricultural concern inhibiting not only plant growth but also the symbiotic association between legume roots and the soil bacteria rhizobia. This symbiotic association is initiated by a molecular dialogue between the two partners, leading to the activation of a signaling cascade in the legume host and, ultimately, the formation of nitrogen-fixing root nodules. Here, we show that a moderate salt stress increases the responsiveness of early symbiotic genes in Medicago truncatula to its symbiotic partner, Sinorhizobium meliloti while, conversely, inoculation with $S$. meliloti counteracts salt-regulated gene expression, restoring one-third to control levels. Our analysis of early nodulin 11 (ENOD11) shows that salt-induced expression is dynamic, Nod-factor dependent, and requires the ionic but not the osmotic component of salt. We demonstrate that salt stimulation of rhizobium-induced gene expression requires $N S P 2$, which functions as a node to integrate the abiotic and biotic signals. In addition, our work reveals that inoculation with $S$. meliloti succinoglycan mutants also hyperinduces ENOD11 expression in the presence or absence of salt, suggesting a possible link between rhizobial exopolysaccharide and the plant response to salt stress. Finally, we identify an accessory set of genes that are induced by rhizobium only under conditions of salt stress and have not been previously identified as being nodulation-related genes. Our data suggest that interplay of core nodulation genes with different

${ }^{\dagger}$ Corresponding author: J. M. Harris: Jeanne.harris@uvm.edu

Funding: Support was provided by Gene Ontology, the National Institute of General Medical Sciences (grants GM093628 and P20GM103449), and Hatch (grant VT-H02104); and Kyoto Encyclopedia of Genes and Genomes pathway analyses were supported by the Vermont Biomedical Research Network (VBRN) Bioinformatics Core.

*The $\boldsymbol{e}$-Xtra logo stands for "electronic extra" and indicates that supplementary materials and a supplementary file are published online.

The author(s) declare no conflict of interest. distributed under the CC BY 4.0 International license. accessory sets, specific for different abiotic conditions, functions to establish the symbiosis. Together, our findings reveal a complex and dynamic interaction between plant, microbe, and environment.

Keywords: ENOD11, exopolysaccharides, exoS, exoY, hyperinduction, infection, Medicago truncatula, nitrogen-fixation, NPL, NSP2, priming, RNA-seq, root nodules, salt stress, Sinorhizobium meliloti, succinoglycan, symbiosis

Legumes are integral to sustainable agriculture because of their high nitrogen content, the product of a mutualistic symbiosis that they form with a group of soil bacteria, collectively known as rhizobium (Graham 2003). The rhizobium-legume symbiosis involves a complex developmental process including both the creation of a new root organ, the nodule, and infection of the nodule by rhizobium, successfully coordinated in space and time (Ferguson et al. 2010; Oldroyd 2013). Within the nodule, differentiated rhizobia reduce atmospheric dinitrogen into ammonium in exchange for carbon from the host (Ferguson et al. 2010). However, the symbiotic interaction between rhizobia and their legume hosts is sensitive to environmental factors, such as extreme temperature, $\mathrm{pH}$, soil nitrogen, drought, and salinity (Murray et al. 2017; Singleton and Bohlool 1984; Zahran 1999).

As our climate changes, rising temperatures lead to increased soil dryness, resulting in the concentration of salts, becoming an accelerating agricultural concern (HanumanthaRao et al. 2016; Sherwood and Fu 2014; St.Clair and Lynch 2010). Salt accumulation is exacerbated by irrigation, and the amount of cropland experiencing salinization is growing at $10 \%$ per year; by 2050 , half of all agricultural land is predicted to be salt stressed (Nachshon 2018). Even moderate salt stress, not sufficient to inhibit growth, can have severe effects on nodulation, negatively regulating multiple aspects of the rhizobium-legume symbiosis (Borucki and Sujkowska 2008; Singleton and Bohlool 1984; Soussi et al. 1998; Tu 1981).

Establishment of the rhizobium-legume symbiosis is orchestrated by a series of signal exchanges between the two partners (Oldroyd 2013). Nodulation is initiated by the synthesis and 
secretion of rhizobial lipochitooligosaccharide signal molecules, known as Nod factors (NF), which signal the plant root, inducing changes in cytoskeletal organization and patterns of cell growth, as well as inducing major changes in gene expression (Roy et al. 2020). NF perception at the host plasma membrane by LysM receptor-like kinases initiates a signaling cascade that triggers nuclear calcium spiking, decoded by the nuclear calciumcalmodulin kinase, encoded by Doesn't Make Infections 3 (DMI3) (Zipfel and Oldroyd 2017). DMI3 signaling induces a transcriptional cascade, mediating changes needed for rhizobial infection, as well as activating cytokinin-dependent signaling in the underlying cortical cells (Catoira 2000; Marsh et al. 2007; Middleton et al. 2007; Mitra et al. 2004a; Murray et al. 2007; Oldroyd and Long 2003; Reid et al. 2017; Rival et al. 2012; Tirichine et al. 2007). These transcription factors act in concert to spatiotemporally modulate the expression of Early Nodulin 11 (ENOD11), one of the earliest markers of rhizobium-legume symbiosis (Cerri et al. 2012; Journet et al. 2001; Vernié et al. 2015). ENOD11 encodes a cell wall glycoprotein associated with the early stages of infection (Cerri et al. 2012; Journet et al. 2001; Vernié et al. 2015). The ENOD11 promoter contains the distal NF-box, to which the transcription factor ERF required for nodulation 1 (ERN1) and the closely related ERN2 bind, activating its expression in patches of epidermal cells (Andriankaja et al. 2007; Cerri et al. 2012). There is a subsequent, rhizobial infection-associated upregulation of ENOD11 mediated by a complex formed by the transcription factors nodulation signaling pathways 1 and 2 (NSP1 and NSP2), which binds a proximal region of the promoter, activating ENOD11 expression independent of ERN1 (Cerri et al. 2012). As symbiosis proceeds, another transcription factor, nodule inception (NIN), competes with ERN1 for binding to the NF-box in the ENOD11 promoter, repressing ENOD11 expression in younger portions of the root system in order to maintain a developmentally sustainable number of nodules (Marsh et al. 2007; Vernié et al. 2015).

Rhizobial infection requires NF signaling, which induces changes within the root and root hair cells, thus preparing them for this process. Infection also requires production of bacterial exopolysaccharide (EPS) (Gage 2004; Jones et al. 2007). Together, these two molecules orchestrate the successful infection of the host root by rhizobia. Within minutes of NF exposure, root hair cells reorganize their cytoskeleton, part of a process of reorienting root hair growth to form tight curls entrapping the signaling rhizobia (Esseling et al. 2003; Jones et al. 2007). The plant rapidly modifies the cell wall of the developing infection chamber, secreting ENOD11 only to this portion of the root hair cell wall (Fournier et al. 2015). Although NF signaling continues to play a role in planta, exit from this infection chamber and successful invasion of the host requires production of EPS (Jones et al. 2007). The predominant EPS produced by Sinorhizobium meliloti is succinoglycan (EPSI). Succinoglycan synthesis, export, and polymerization are controlled by the exo gene products (Jones et al. 2007). S. meliloti exoY mutants are unable to synthesize succinoglycan, and remain trapped in the root-hair-enclosed infection chamber (Cheng and Walker 1998). In contrast, root hair curls containing succinoglycan-synthesizing $S$. meliloti form an infection thread (IT), a tubular, transcellular apoplastic compartment, which initiates from the infection chamber, passing through the root hair cell and extending through underlying cortical cells; it is through this structure that the bacteria gain entry into the root. Localized cell wall degradation and inward growth of both the host cell wall and plasma membrane are needed for both initiation and extension of the IT (Fournier et al. 2008; Gage 2002, 2004). NF signaling induces expression of the host protein nodule pectate lyase (NPL), a cell-wall-degrading enzyme, which has been implicated in the process of infection, thus indicating a continuing role for NF signaling in the infection process (Xie et al. 2012). In Lotus japonicus, NF induces expression of the LysM receptor kinase, EPR3, which binds the Mesorhizobium loti EPS octasaccharide and is required for progression of the IT through the root hair and into the root cortex and nodule primordium (Kawaharada et al. $2015,2017)$. Thus, infection is initiated by NF signaling but entry into the root requires EPS.

Massive transcriptional reprogramming accompanies the initial response of plants to the symbiotic signals NF and succinoglycan as well as abiotic stresses such as salinity (Breakspear et al. 2014; Damiani et al. 2016a; Jones et al. 2008; Kreps et al. 2002; Larrainzar et al. 2015; Li et al. 2011; Mitra et al. 2004b; Shaar-Moshe et al. 2017; van Zeijl et al. 2015b). Perception of these biotic and abiotic signals result in transcriptional cascades that alter the expression pattern of thousands of genes and trigger hormone signaling to coordinate the plant response. Salt stress responses are mediated primarily by abscisic acid (ABA) and ethylene but gibberellins (GAs) and cytokinins also play an important role ( $\mathrm{Ku}$ et al. 2018; Śmura et al. 2018; M. Zhang et al. 2016). All of these hormones also function in early root responses to NF and in subsequent organogenesis (Ferguson and Mathesius 2014). In particular, $\mathrm{ABA}$ and ethylene modulate the calcium spiking that functions upstream of the transcriptional cascade in the NF response, thus having the ability to block the response just after NF perception. Subsequently, ABA inhibits cytokinin induction of gene expression and strongly reduces nodule number (Ding et al. 2008; Oldroyd et al. 2001). Altering the signaling of any one of these hormones has profound effects on the transcriptome, thus leading to waves of transcriptional changes in response to these abiotic and biotic signals (Brenner and Schmülling 2012; Larrainzar et al. 2015; Luo et al. 2018; Okamoto et al. 2010; Xie et al. 2016).

Rhizobium-legume symbiosis is particularly sensitive to salinity compared with the individual partners involved in this process. Salt concentrations that are too low to limit photosynthesis can inhibit nodulation of chickpea (Soussi et al. 1998), while freeliving S. meliloti (strain Rm1021) is tolerant to up to $400 \mathrm{mM}$ $\mathrm{NaCl}$ (Domínguez-Ferreras et al. 2006). Salt stress interferes with rhizobial infection, inhibiting root hair curling, rhizobial invasion, and release of rhizobia into nodule cells, producing fewer, less efficient nodules (Borucki and Sujkowska 2008; Cordovilla et al. 1994; Singleton and Bohlool 1984; Tu 1981; Zahran and Sprent 1986). Because of the central role of biological nitrogen fixation in sustainable agriculture and the increasing salinization of agricultural land, it is important to understand the mechanism of salt stress interference with symbiotic legume root nodule initiation and establishment.

The model legume Medicago truncatula is a Mediterranean species and displays a range of salt tolerance across natural populations (Soumaya et al. 2011). The genotype Jemalong A17 (used in this work) is widely used as a system for nodulation studies and is moderately tolerant to salt (de Lorenzo et al. 2007; Zahaf et al. 2012). Several genes in $M$. truncatula function in response to salt stress (Ariel et al. 2010; de Lorenzo et al. 2009; Gruber et al. 2009; Li et al. 2009, 2011; Merchan et al. 2003; 2007). NAC969 is involved in both salt stress tolerance and nodule senescence, and its downregulation is associated with increased salt tolerance but aberrant nodules (de Zélicourt et al. 2012). Salinity is one of the key drivers of local adaptation in $M$. truncatula (Guerrero et al. 2018). The identification of specific genetic changes in $M$. truncatula associated with local adaptation to salt and to climatic variation in temperature and precipitation, as well as the identification of selective sweeps targeting nodulation genes, indicates the importance of both the rhizobial symbiosis and the salt response to legume survival and fitness (Bonhomme et al. 2015; Friesen et al. 2014; Yoder et al. 2014). Thus, we chose to examine the link between moderate salt stress and early symbiotic signaling. The focus on mild to moderate stress, as opposed to severe stress, 
means that the stress responses are studied within a context of plant growth, not arrest, and has been proposed as an approach that may reveal new cellular mechanisms (Verslues 2017).

Here, we show that a moderate salt stress not sufficient to affect plant growth severely inhibits nodulation and rhizobial colonization yet stimulates the expression of several early symbiotic genes, increasing their responsiveness to NF. This hyperinduction is mediated by NSP2, and requires the ionic but not the osmotic component of salt. Inoculation with rhizobial succinoglycan mutants also increases the responsiveness of ENOD11 expression to NF. In contrast, rhizobium inoculation antagonizes the effect of salt stress on the expression of over 100 genes. Finally, we report a set of genes induced by rhizobia only in the presence of salt stress, suggesting the existence of an accessory set of genes specific for nodulation under abiotic stress. Thus, our work reveals a complex interaction between salt stress and symbiosis, in which the abiotic environment influences the biotic interaction, with NSP2 acting as a node to integrate environmental conditions and symbiotic signaling.

\section{RESULTS}

\section{A moderate salt stress strongly inhibits nodulation.}

In order to study the effect of salinity on nodulation, we established growth conditions in which $M$. truncatula seedlings were grown in a defined medium with sufficient water throughout the course of our experiments and were exposed to a concentration of salinity that strongly inhibited nodulation but did not impact overall root or shoot growth, and at which Rm1021 growth kinetics were unaffected (Miller-Williams et al. 2006) (Fig. 1). We found an $89 \%$ reduction in the number of nodules under a constant exposure to $100 \mathrm{mM} \mathrm{NaCl}$; these nodules were globular, mostly white, sometimes brown, in contrast to well-developed pink nodules observed in the control condition. (Fig. 1A and B). Very few of these nodules showed expression of nifH, which encodes one of the subunits of nitrogenase, indicating that these are mostly nonfunctional nodules (Chakraborty 2018). In contrast, this salt treatment had a mild effect on overall growth of the plant during the timeframe of our experiment, with no significant change in primary root length, shoot biomass, or chlorophyll $a$ content (Fig. $1 \mathrm{C}$ to $\mathrm{E})$, although we did observe a significant decrease in chlorophyll $b$ content (Fig. 1E). Thus, under our growth conditions, $100 \mathrm{mM} \mathrm{NaCl}$ acts as a moderate salt stress, which severely affects nodulation but has only a modest effect on root and shoot growth.

\section{General response of $M$. truncatula root transcriptome to salinity and rhizobium.}

Because we observed a strong reduction in the number of nodules under salt stress, we hypothesized that it would interfere with nodulation at a relatively early step. Given that significant transcriptional changes occur in the host root during the first day after inoculation with rhizobia (Breakspear et al. 2014; Larrainzar et al. 2015; Mitra et al. 2004b), we profiled the transcriptomes of saltstressed and control primary roots with or without rhizobial inoculation at 1 day postinoculation (dpi). We hoped to identify both changes to expression of known nodulation-associated genes as well as the identification of genes that are associated with nodulation under stress conditions and thus might be missed in standard transcriptome analysis.

Principal component analysis revealed that the majority of variation (40\%) was associated with salt, likely due to the longer salt treatment (5 days) as opposed to rhizobium treatment (1 day), and also that one replicate did not cluster with other samples from the same treatment group (Fig. 2A). To ensure that inclusion of this outlier did not bias our results, we analyzed the RNA sequencing (RNA-seq) data both with and without this sample (both datasets are provided in Supplementary File S1). This comparison revealed that the majority of differentially expressed genes (DEGs) were shared between these analyses and, hence, we focused on these DEGs (for comparison, see Supplementary Figure S1 and Supplementary File S1). The strongest transcriptional response we observed was to salt stress, with 641 DEGs identified in samples containing a salt treatment $(+\mathrm{S})$, either with $(+\mathrm{R})$ or without $(-\mathrm{R})$ rhizobial inoculation (Fig. 2B; Supplementary File S1). As expected, this set included upregulation of several genes associated with salt stress and ABA signaling, including genes encoding ABA 8'-hydroxylases, dehydrins, responsive to dehydration 22 (RD22), late embryogenesis abundant (LEA) proteins, and a dehydration-responsive element-binding protein (Medtr1g101600) (Supplementary File S1). Kyoto Encyclopedia of Genes and Genomes (KEGG) pathway enrichment analysis further supported the strong effect of salt stress on the transcriptome, with the maximum number of significantly enriched pathways observed in its presence (Fig. 2C).

In contrast, we saw only 36 genes that were differentially expressed after rhizobium inoculation (Fig. 2B). This is fewer than reported in other studies and may be due to our growth conditions or the fact that the whole root was used instead of just the responsive zone or specific tissues or cell types. Most of the rhizobia-induced genes we identified were previously shown to be involved in nodulation, and include ENOD11, ERN1, NIN, MtNPL, nuclear factor YA-1 (NF-YAI), LOB domain protein 16 (LBD16), vapyrin (VPY), rhizobium-directed polar growth $(R P G)$, vestitone reductase cluster2 (VRC2), $\beta$-carotene isomerase DWARF27 (D27), and a glycine-rich peptide (Tables 1 and 2; Supplementary File S1) (Arrighi et al. 2008; Breakspear et al.
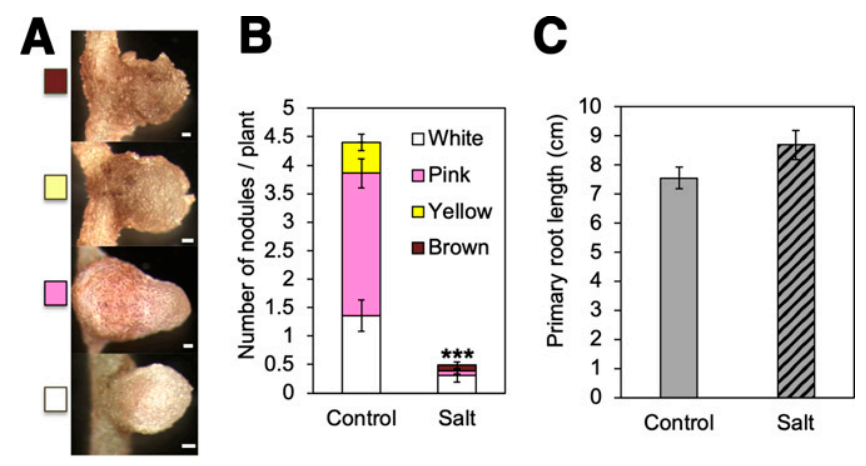

D
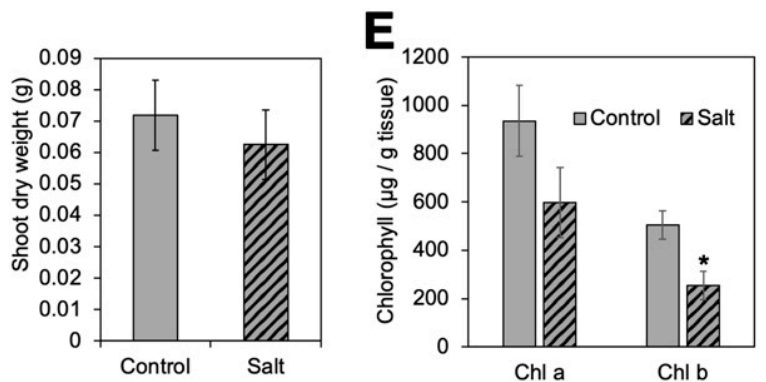

Fig. 1. Moderate salt stress inhibits nodulation but not root or shoot growth. Effect of $100 \mathrm{mM} \mathrm{NaCl}$ on $\mathbf{A}$ and $\mathbf{B}$, nodulation; $\mathbf{C}$, primary root length; D, shoot dry weight; or $\mathbf{E}$, chlorophyll (chl) content. Nodules visually categorized at 14 days postinoculation based on stages of development as immature (white), mature (pink), senescing or stressed (yellow), or severely senescing or stressed (brown) (A); color-coding of nodules matches the graph in B. Primary root length from $n=14$, shoot dry weight from $n=21$, and chlorophyll content from $n=14$ seedlings per treatment per experiment. Data plotted as least square means $(\mathrm{LSM}) \pm$ standard error of the mean from three independent experiments. Significance tested by pairwise comparison of $\operatorname{LSM}(\alpha=0.05)$ and significant differences shown by asterisks ( $*$ and $* * *$ denote $P<0.05$ and 0.0005 , respectively). Asterisks in $B$ reflect a significant difference in the total number of nodules (all colors) between treatments. Scale bar $=0.1 \mathrm{~mm}$. 

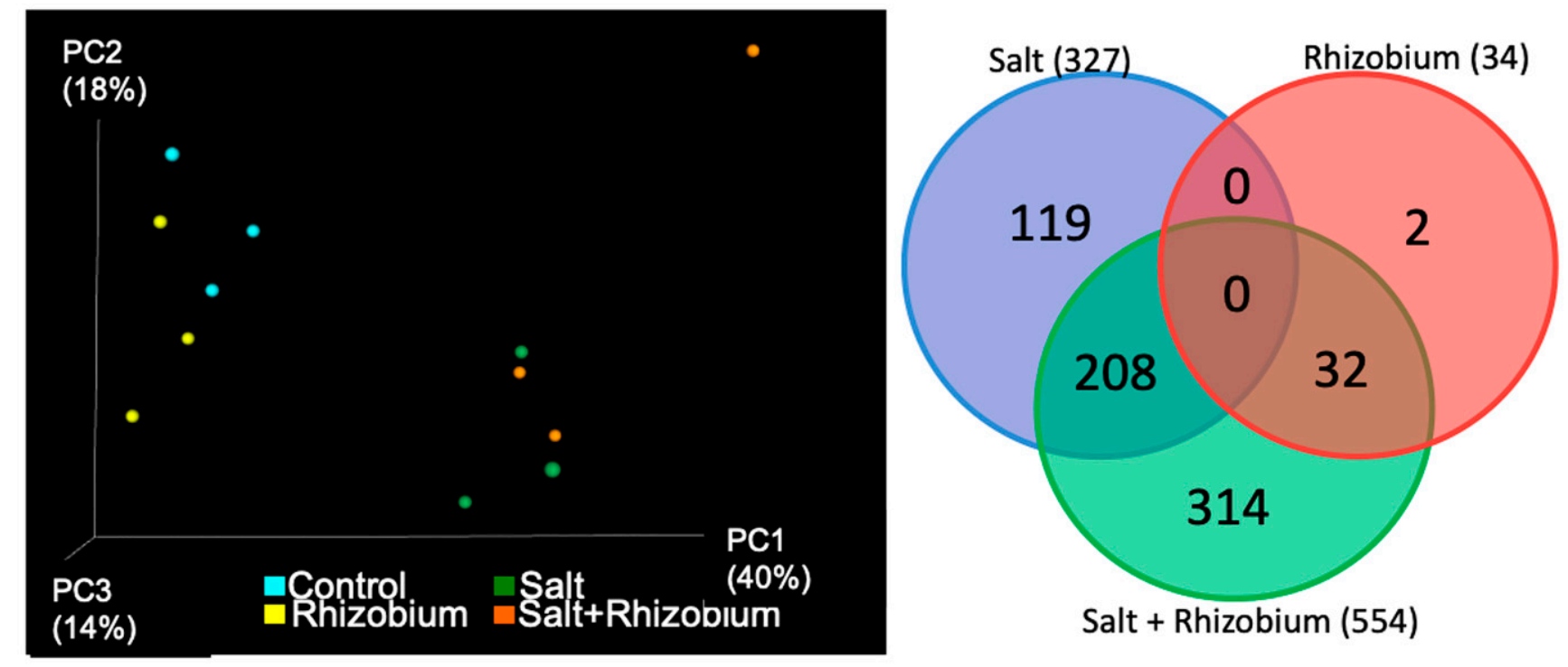

C

\section{KEGG pathways}

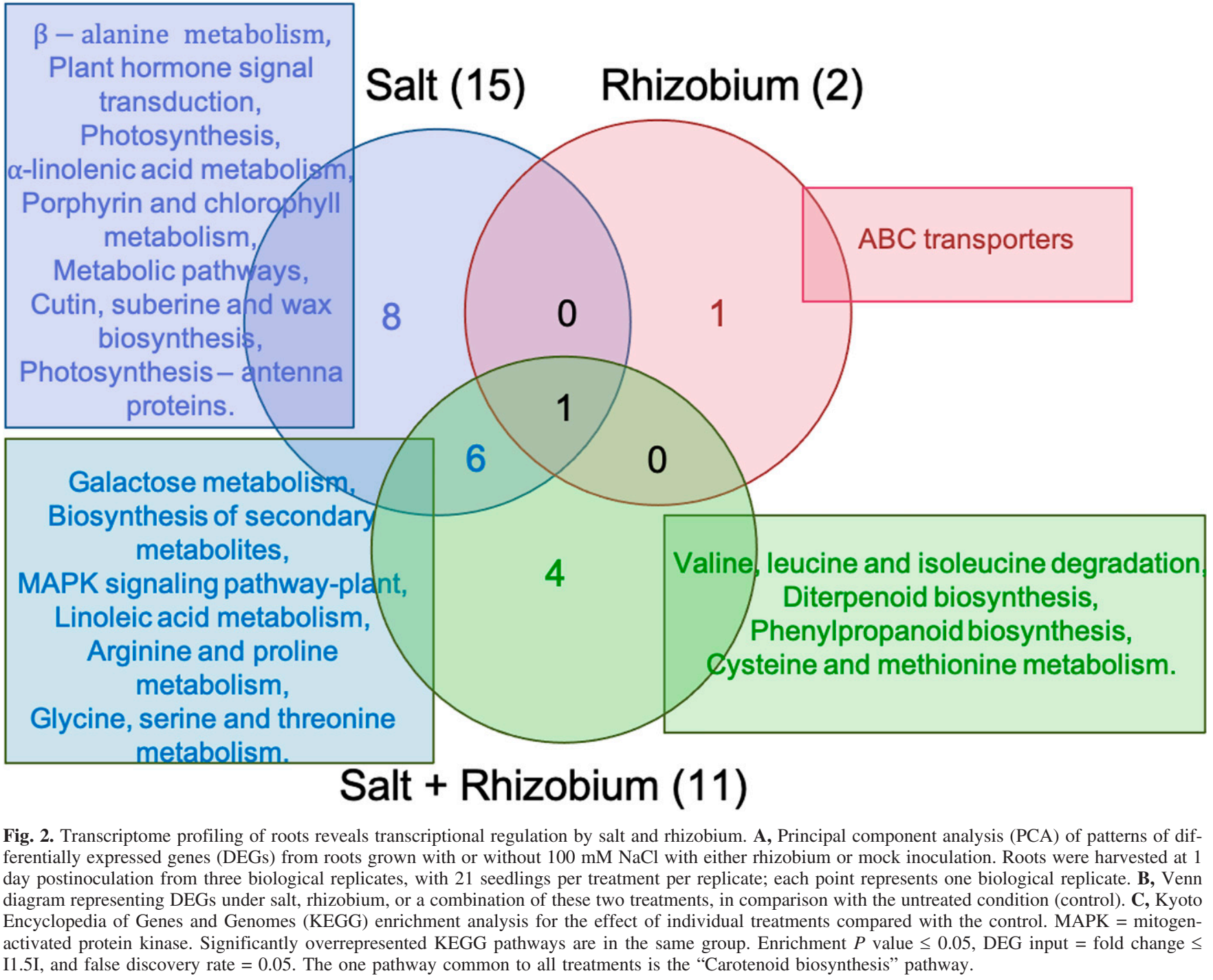


2014; Cerri et al. 2012; Jardinaud et al. 2016; Journet et al. 2001; Laporte et al. 2014; Marsh et al. 2007; Middleton et al. 2007; Murray 2011; Schiessl et al. 2019; Soyano et al. 2019; van Zeijl et al. 2015b; Vernié et al. 2015; Wang et al. 2016; Xie et al. 2012).

Table 1. Rhizobium-responsive genes that are significantly upregulated by salt stress ${ }^{\mathrm{a}}$

\begin{tabular}{|c|c|c|}
\hline Gene & Fold change & Description \\
\hline Medtr3g415670 & 8.37281988 & $\begin{array}{l}\text { Transmembrane protein, putative } \\
\text { (ENOD11) }\end{array}$ \\
\hline Medtr3g086320 & 7.52697871 & Pectate lyase family protein $(M t N P$ \\
\hline Medtr3g112460 & 6.76060631 & $\begin{array}{l}\text { Nitrate transporter } 1 / \text { peptide } \\
\text { transporter family }\end{array}$ \\
\hline Medtr8g012795 & 6.69379079 & Defensin-like \\
\hline Medtr7g074730 & 6.21891491 & $\begin{array}{l}\text { Dihydroflavonol 4-reductase-like } \\
\text { protein (VRC2) }\end{array}$ \\
\hline ledtr8g040940 & 1732 & Hypothetical protein \\
\hline 5470 & & rotease inhibito \\
\hline Medtr4g081190 & 5.47579623 & $\mathrm{ABC}$ transporter $\mathrm{B}$ family protein \\
\hline Medtr5g011960 & 4.28478737 & Lipid transfer protein \\
\hline Medtr4g117000 & 4.26927542 & $\begin{array}{l}\text { Glycoside hydrolase family } 18 \\
\text { protein }(M t C H I T b)\end{array}$ \\
\hline Medtr5g019460 & 4.15736244 & $\begin{array}{l}\text { Geranylgeranyl pyrophosphate } \\
\text { synthase (GGPS1) }\end{array}$ \\
\hline Medtr8g022270 & 4.08146484 & $\begin{array}{l}\mathrm{ABC} \text { transporter } \mathrm{B} \text { family-like } \\
\text { protein }\end{array}$ \\
\hline Medtr1g090807 & 3.829778 & $\begin{array}{l}\text { Myosin heavy chain-like protein, } \\
\text { putative }(M t R P G)\end{array}$ \\
\hline Medtr4g088510 & & Hypothetical protein \\
\hline Medtr6g027840 & 3.73624957 & $\begin{array}{l}\text { Ankyrin repeat RF-like protein, } \\
\text { putative }(M t V A P Y R I N)\end{array}$ \\
\hline Medtr3g031270 & & Wound-induced-like protein \\
\hline Medtr4g076255 & 3.26161212 & Glucan endo-1,3- $\beta$-glucosidase \\
\hline Medtr3g087730 & 3.21429686 & $\begin{array}{l}\text { Sulfate/bicarbonate/oxalate } \\
\quad \text { exchanger and transporter (sat-1) }\end{array}$ \\
\hline & & Nodule-specific glycine rich peptide \\
\hline Medtr3g436390 & 2.03117086 & Flavonoid hydroxylase \\
\hline
\end{tabular}

${ }^{a}$ Genes listed by descending order of fold change with salt. Fold change calculated between salt-supplemented rhizobium-inoculated samples $(+\mathrm{R}+\mathrm{S})$ and rhizobium-inoculated samples $(+\mathrm{R}-\mathrm{S})$ excluding the outlier sample. Medtr3g436390 and Medtr4g076255 are repressed by rhizobium inoculation in the absence of salt. All other genes are induced by inoculation in the absence of salt stress. In addition to the listed genes, ERN1 was observed to be hyperinduced by salt using quantitative reverse-transcription PCR (Supplementary Fig. S8). Top Arabidopsis protein BLAST results are provided in Supplementary Table S1.

Table 2. Rhizobium-responsive genes that are not affected by salt stress ${ }^{\mathrm{a}}$

\begin{tabular}{ll}
\hline Gene & \multicolumn{1}{c}{ Description } \\
\hline Medtr0011s0280 & Putative oxidoreductase \\
Medtr1g056530 & CCAAT-binding transcription factor (NF-YA1) \\
Medtr1g471050 & Putative $\beta$-carotene isomerase (D27) \\
Medtr2g019750 & AP2 domain class transcription factor \\
Medtr3g081140 & Cysteine-rich TM module stress tolerance protein \\
Medtr3g103260 & Hypothetical protein \\
Medtr5g025850 & Leucine-rich repeat receptor-like kinase \\
& family protein \\
Medtr5g075400 & Hypothetical protein \\
Medtr5g099060 & Nodule inception protein (NIN) \\
Medtr6g007160 & Transmembrane protein, putative \\
Medtr6g007690 & Serine-threonine kinase \\
Medtr6g056070 & Putative salicylate carboxymethyltransferase \\
Medtr7g085810 & AP2 domain class transcription factor (ERN1) \\
Medtr7g096530 & Lateral organ boundaries domain TF (LBD16)
\end{tabular}

a All genes listed had no significant change in expression between sitsupplemented rhizobium-inoculated samples $(+R+S)$ and rhizobiuminoculated samples $(+\mathrm{R}-\mathrm{S})$ in the core set of genes. The expression of NIN $(+\mathrm{R}+\mathrm{S}$ versus $+\mathrm{R}-\mathrm{S})$ was further tested with quantitative reverse-transcription PCR with similar results (Supplementary Fig. S8). Top Arabidopsis protein BLAST results are provided in Supplementary Table S2.
We also observed induction of a gene encoding the chitinase $M t C H I T b$, which can be converted into a NF hydrolase (L.-Y. Zhang et al. 2016).

\section{Complex interplay between salinity and rhizobium in their regulation of gene expression.}

To better understand the interplay between salinity and rhizobium in regulating gene expression, we analyzed rhizobium-responsive genes that are influenced by salinity and salt-responsive genes that are influenced by rhizobium. We found that 32 of the 36 rhizobium-regulated genes identified in our rhizobium in the absence of salt $(+\mathrm{R}-\mathrm{S})$ treatment were also regulated by rhizobium in the presence of salt $(+\mathrm{R}+\mathrm{S}$ treatment $)$. Of these, the expression of 20 was significantly different in the $+\mathrm{R}+\mathrm{S}$ treatment relative to $+\mathrm{R}-\mathrm{S}$, indicating that the level of expression had changed (Fig. 2B; Supplementary File S1). Surprisingly, rather than inhibiting expression, as we predicted from salt's inhibition of nodulation, a moderate salt stress instead stimulated expression of all 20 genes (Table 1). This stimulation of expression included two genes that had been repressed by inoculation (Medtr3g436390, encoding a flavonoid hydroxylase, and Medtr4g076255, encoding a glucan endo1,3 - $\beta$-glucosidase), thus returning them to control levels. The remaining salt-enhanced rhizobium-induced genes were previously found to be upregulated by NF as early as $3 \mathrm{~h}$ postapplication (Damiani et al. 2016a; Jardinaud et al. 2016; van Zeijl et al. 2015b). Rhizobium-responsive genes that were unaffected by salt stress included the transcription factors NIN, ERN1, NF-YA1, LBD16, and D27 (Table 2). ENOD11 showed the highest hyperinduction by salt, closely followed by $M t N P L$, suggesting that salt stress particularly enhances expression of early rhizobiuminduced genes (Table 1). We subsequently showed by quantitative reverse-transcription (qRT)-PCR that ERNI was significantly induced by salt but NIN was not (Supplementary Fig. S8).

In contrast to the enhancement of rhizobium-responsive genes by salt, we observed the opposite effect of rhizobium treatment on saltregulated genes. We found that, of the 327 genes differentially expressed by salt in the absence of rhizobium $(-\mathrm{R}+\mathrm{S}), 119$ of them were no longer significantly different from control levels in the combined treatment $(+R+S)$, indicating that the rhizobium treatment antagonized the effect of salt treatment on one-third of the genes. The majority $(70 \%)$ of these 119 DEGs were upregulated by salt, indicating that rhizobium inoculation suppressed their induction (Supplementary File S1). This category included genes associated with salt stress and ABA signaling, encoding a LEA (Medtr7g093140), a dehydrin (Medtr7g086340), and an ABA 8'-hydroxylase (Medtrlg019410), as well as several encoding putative transcription factors, leucine-rich repeat (LRR) receptor-like kinase family proteins, proteins associated with lipid metabolism, and chlorophyll-binding proteins. A KEGG pathway enrichment analysis of the salt-regulated genes whose induction or repression is reversed by rhizobium inoculation indicates overrepresentation of genes involved in $\beta$-alanine metabolism, plant hormone signal transduction, photosynthesis, $\alpha$-linolenic acid metabolism, porphyrin and chlorophyll metabolism, metabolic pathways, cutin, suberin and wax biosynthesis, and photosynthesis-antenna proteins (Fig. 2C), indicating the broad impact of rhizobium on salt stress responses in the plant root. Notably, this set also included NSP2, which was repressed by salt alone, a result that we confirmed with qRT-PCR (Supplementary Fig. S8).

\section{Salt-rhizobium cotreatment strongly upregulates several symbiotic genes.}

Given the strong stimulatory effect of salt on rhizobiumresponsive genes, we next focused our attention on the set of DEGs observed exclusively in the combined presence of salt and rhizobia. We observed 314 DEGs in this set, which is the largest number of DEGs observed exclusively with any treatment in 
our study (Supplementary File S1); of these, 216 (65.6\%) were upregulated. Interestingly, 147 were previously identified as being responsive to purified NF or rhizobial inoculation in other studies (Damiani et al. 2016a; Jardinaud et al. 2016; van Zeijl et al. 2015b). The fact that we detected these DEGs only in the combined presence of salt and rhizobium further corroborates a strong positive regulation of salt stress on these rhizobium-responsive genes, such that the expression levels could cross the threshold of detection in our study. Interestingly, only a few of the repressed genes in this set have been shown to be induced during nodulation (21 of 147), indicating that, at this time point, the main effect of salt stress is not to repress nodulation-associated genes but, rather, to stimulate rhizobium-induced gene expression. We did not observe a strong correlation between expression patterns of genes in this set and those observed with a 2-day drought treatment on mature nodules, highlighting the complex interaction between development, environment, and symbiosis (Sańko-Sawczenko et al. 2019) (Supplementary File S1). Gene ontology (GO) term and KEGG pathway enrichment analyses of the genes differentially expressed only in the $+\mathrm{R}+\mathrm{S}$ dataset highlighted overrepresentation of a diverse set of processes (Fig. 2C; Supplementary Figs. S2 and S3).

Several of the nodulation-associated genes in this set that were upregulated in the rhizobium and salt cotreatment only were previously known to play a role in early stages in nodulation. In particular, we identified genes encoding several LysM receptor-like kinases (LYK), one of which, LYK-related 3 (LYR3), is one of the putative NF receptors (Fliegmann et al. 2016), and another, LYK10 (Maillet et al. 2020), which plays a role in infection. We detected additional genes encoding kinases in this set, including the tyrosine kinase SPK1, whose expression is upregulated by both NF and hydrogen peroxide (Andrio et al. 2013; Jardinaud et al. 2016) and is involved in nodule formation, and the LRR receptor kinase Medtr6g036780, which is one of the most highly induced genes in this set, upregulated approximately 150-fold (Supplementary File S1).

We detected upregulation of other genes associated with early events in the rhizobium-legume interaction in this set, including the gene encoding the transcription factor NSP1, which binds the ENOD11 promoter (Catoira 2000; Cerri et al. 2012; Hirsch et al. 2009; Smit et al. 2005), genes associated with rhizobial infection, such as ENOD12 (Journet et al. 1994), which is closely related to ENOD11, cystathionine- $\beta$-dynthase-like domaincontaining protein 1 (CBS1) (Sinharoy et al. 2016), seven in absentia (SINA) (Den Herder et al. 2008), and a gene encoding the putative rhicadhesin receptor (Medtr2g031270). The rhicadhesin receptor and $C B S 1$ were among the most strongly upregulated genes, exhibiting over 150- and 200-fold induction, respectively, compared with the control. In the set of genes including all three replicates, we further detected annexin 1 (MtAnnl), which is thought to be involved in mitotic reactivation of cortical cells prior to infection (de Carvalho Niebel et al. 1998), and CLAVATA3/ embryo-surrounding region 13 (CLE13) involved in autoregulation of nodulation; the expression of the latter is also detected in cortical cells undergoing mitotic reactivation during nodule organogenesis (Laffont et al. 2018; Mortier et al. 2010, 2012) (Supplementary File S1).

Cortical NIN acts through cytokinin and its receptor cytokinin response 1 (CRE1) to initiate nodule organogenesis (Vernié et al. 2015). We observed upregulation of several NIN-regulated genes with salt-rhizobium cotreatment, including $C B S 1, N P L, R P G$, $A N N 1$, and LYR3 (Liu et al. 2019) (Supplementary File S1). Combined with the differential regulation of CLE13 (upregulated) and the nitrate-responsive CLE35 that regulates nodule number (downregulated) (Mens et al. 2020), our data suggest that, at this 1-dpi time point, salt hyperinduces genes associated with the cortical response pathway.

\section{A previously unidentified set of genes associated with nodulation under salt stress.}

Although nodulation is strongly inhibited by a moderate salt stress, nodulation does occur (Fig. 1). Transcriptome analysis of the early responses to rhizobium is usually carried out on plants grown in ideal growth conditions. A major goal of this study was to identify genes that might be required for nodulation under stress conditions, which might be missed under ideal conditions. Although we identified many genes known to function or be expressed during nodulation, 53.2\% (167 of 314) of the genes exclusively induced in our $+\mathrm{R}+\mathrm{S}$ set were not previously shown to be involved in nodulation. Some of these were among the most highly expressed genes.

We found a number of genes associated with detoxification. In particular, this set included 12 members of the cytochrome P450 superfamily, 4 of which were downregulated and 8 upregulated. Of those, three of the downregulated and two of the upregulated genes were not previously linked to early nodulation. Two glutathione S-transferase genes were upregulated, including one, Medtr5g076900, which was among one of the most highly induced genes (55-fold). We also identified 14 upregulated genes annotated as heavy metal transport/detoxification superfamily (MATE efflux family) proteins or other heavy metal-associated proteins, none of which had been previously associated with nodulation. Two of these genes, Medtr3g434890 and Medtr $7 g 451200$, were upregulated approximately 80- and 100-fold, respectively (Supplementary File S1).

The transcriptional reprogramming triggered by the joint treatment of salt stress and rhizobium inoculation also included altered regulation of many genes with a likely role in signaling. Multiple F-box proteins, LRR receptor-like kinases, lectin receptor-type kinases, and others changed expression. In addition, many genes with homology to genes encoding disease resistance proteins of different classes - toll interleukin 1 receptor nucleotide binding site (NBS)-LRR; LRR; nucleotide-binding adaptor shared by APAF-1, R proteins, and CED-4; and coiled-coil-NBS-LRR-are either up- or downregulated, suggesting altered defense signaling.

\section{Salt stress dynamically regulates symbiotic ENOD11.}

Our transcriptome profiling data revealed that salt enhanced the expression of several symbiotic genes to various degrees. Of all the rhizobium-induced genes whose expression was further stimulated by salt, ENOD11 showed the strongest hyperinduction (Table 1). Given this strong hyperinduction, we chose ENOD11 for further analysis. To better understand how salt stress regulates ENOD11, we analyzed its expression at 2, 3, and $5 \mathrm{dpi}$, in addition to $1 \mathrm{dpi}$, the time point at which the transcriptome profiling was done. In validation of our RNA-seq findings, we observed a strong hyperinduction (10.2-fold with qRT-PCR), as well as an expanded zone of pENOD11:uidA expression by salt at 1 dpi (Fig. 3; Supplementary Fig. S4). At subsequent time points (2 and 3 dpi), the difference in transcript levels between the salt-treated and control seedlings was not significant but, at $5 \mathrm{dpi}$, we found salt to significantly inhibit ENOD11 expression (2.8-fold reduction) (Fig. 3). Consistent with RNA-seq, we could not detect ENOD11 transcript in uninoculated roots in the presence or absence of salt stress, nor did we observe any $\beta$-glucuronidase (GUS) staining in uninoculated $p E N O D 11$ : uidA roots, indicating that salt stress alone cannot induce ENODI1 (Fig. 4).

Plant response to salt stress is predominantly mediated by the phytohormones ABA and ethylene (Duan et al. 2013). Ethylene is an important mediator of salt stress in Arabidopsis thaliana (Cao et al. 2008; Chen et al. 2012) and a powerful inhibitor of early NF signaling, altering the frequency of calcium spiking and reducing symbiotic ENOD11 expression (Oldroyd et al. 2001). Due to its dual roles in salt stress and NF signaling, we investigated whether ethylene mediates the hyperinduction of 
ENOD11 expression by salt stress, using the ethylene-insensitive sickle (skl) mutant (Penmetsa and Cook 1997; Penmetsa et al 2008). We found that salt-induced ENOD11 hyperinduction at 1 dpi was the same in wild-type and skl plants, indicating that

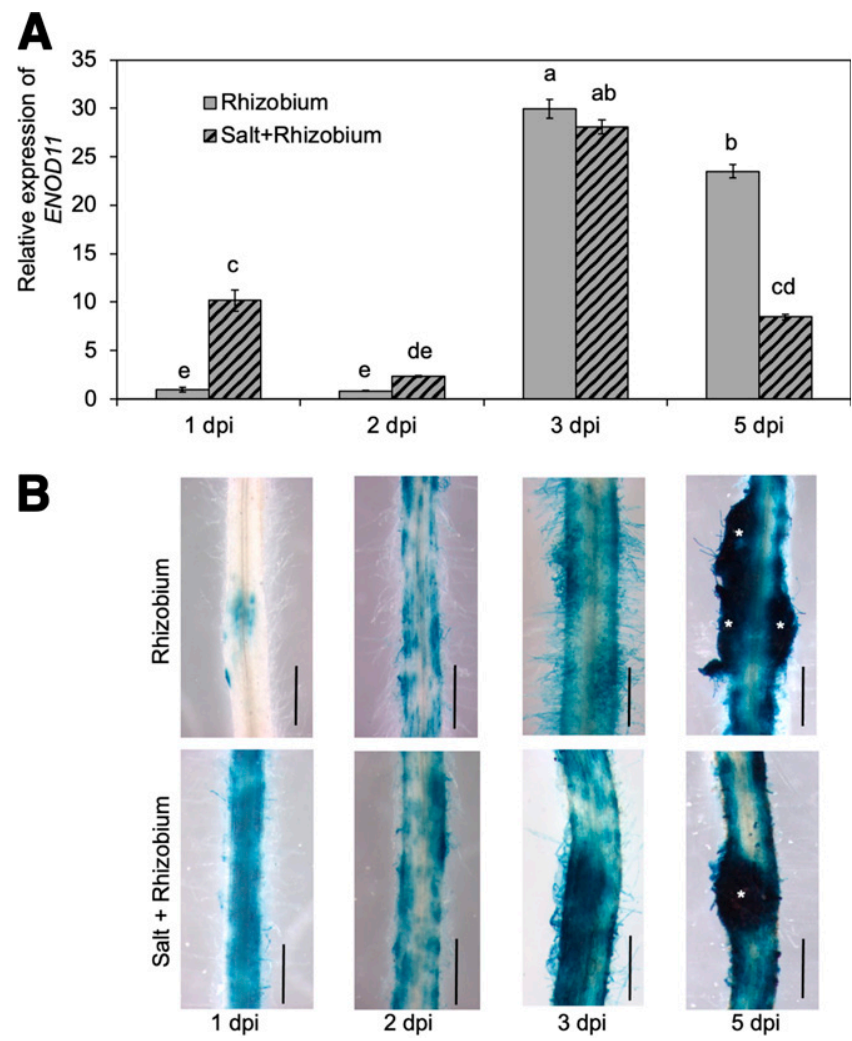

Fig. 3. Salt stress dynamically regulates symbiotic early nodulin 11 (ENOD11) expression. A, ENOD11 expression as measured by quantitative reverse-transcription (qRT)-PCR and $\mathbf{B}$, the corresponding $p E N O$ D11:uidA expression using histochemical assay in inoculated seedlings grown in the presence or absence of $100 \mathrm{mM} \mathrm{NaCl}$; dpi = days postinoculation. Transcript levels showing the mean and the images representative of three independent experiments, with $n=14$ (histochemical assay) or $n=21$ (qRT-PCR) per treatment per experiment. Statistical analysis was done using a two-way analysis of variance followed by $t$ test on the least square means $(\alpha=0.05)$. Columns not connected by the same letter are significantly different. Error bars represent standard error of the mean. Scale bar $=0.5 \mathrm{~mm}$. An asterisk $\left(^{*}\right)$ indicates a developing nodule. Expression levels with the salt-alone treatment were below the limit of detection in qRT-PCR.

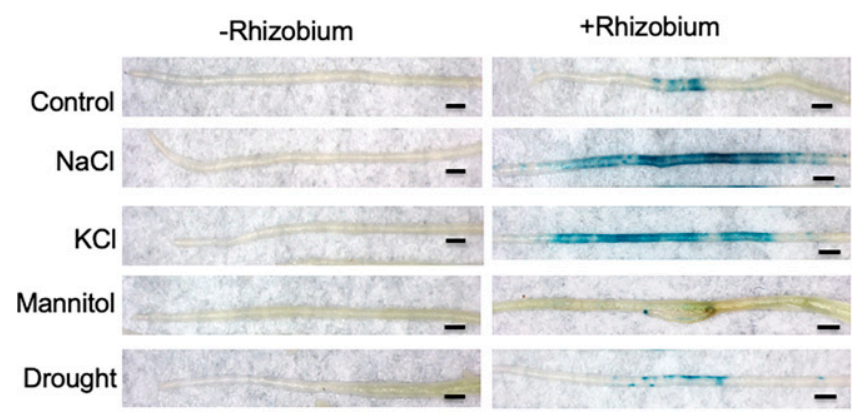

Fig. 4. Hyperinduction of symbiotic early nodulin 11 (ENOD11) occurs in response to salt, not drought or osmotic stress. $p E N O D 11$ :uidA expression at 1 day postinoculation in seedlings subjected to salt stress $(100 \mathrm{mM} \mathrm{NaCl}$ or $\mathrm{KCl}$ ), the equivalent osmotic stress (200 $\mathrm{mM}$ mannitol), or drought (seedlings maintained in half the volume of nutrient medium). Representative images from three independent experiments $(n=7$ per treatment per experiment). Scale bar $=1 \mathrm{~mm}$. ethylene signaling is not required for salt-regulated enhancement of ENOD11 expression (Supplementary Fig. S5).

Salt stress is known to increase ABA levels in roots (Jia 2002), and ABA addition inhibits ENOD11 expression (Ding et al. 2008). We tested whether the dynamic expression profile of ENOD11 under salt stress reflected changing ABA levels in our system. To this end, we quantified $\mathrm{ABA}$ in the same region of the root where we observed ENOD11 hyperinduction (1 dpi) and inhibition ( $5 \mathrm{dpi}$ ) by salt. We did not observe any significant difference in ABA levels between samples at 1 dpi. At 5 dpi, however, we found that roots treated with the combined salt and rhizobium treatment showed a significant increase in ABA, indicating that the combination of salt stress and rhizobium inoculation causes a stronger increase in ABA accumulation than either treatment alone (Fig. 5), and suggesting that the decrease in ENOD11 expression at this time point may be due to the increase in ABA levels.

Together, our results reveal a dynamic regulation of ENOD11 by salt stress in the presence of rhizobium, causing an early upregulation but inhibiting expression at a later stage of symbiosis, the latter response correlating with increased $\mathrm{ABA}$ accumulation.

\section{Early hyperinduction of symbiotic ENOD11 is due} to the ionic effect of salt.

Salt imparts a two-fold stress: (i) osmotic, in which a sudden encounter with an excessive number of molecules leads to dehydration of plant cells via exosmosis, and (ii) ionic, where, due to physicochemical similarities with the macronutrient $\mathrm{K}^{+}$, cations in the salts disrupt cellular processes such as enzyme activity and protein translation (Tester 2003). To test whether ENOD11 hyperinduction in the presence of $\mathrm{NaCl}$ is the result of an ionic imbalance or a result of osmotic stress, we subjected seedlings to a sodic or nonsodic salt (100 $\mathrm{mM} \mathrm{NaCl}$ and $\mathrm{KCl}$, respectively), an equivalent osmotic stress (200 mM mannitol), or water restriction. Our results show that ENOD11 hyperinduction was triggered by salt treatments (both sodic and nonsodic) but not by nonsalt osmotic stress or drought, and that this salt response is contingent on the presence of rhizobia (Fig. 4).

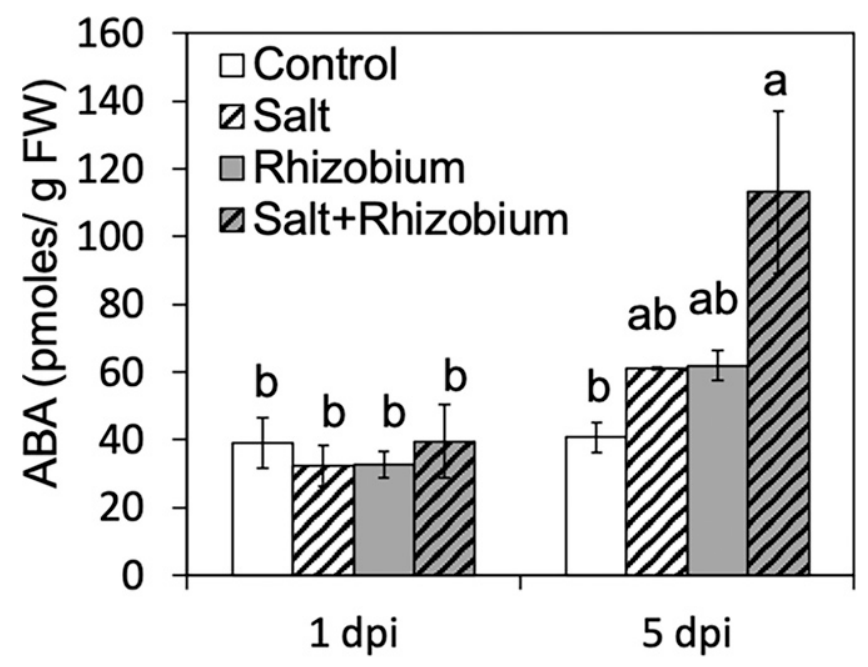

Fig. 5. Salt and rhizobium together cause an increase in root abscisic acid (ABA) concentration at 5 days postinoculation (dpi). ABA quantification was determined by enzyme-linked immunosorbent assay. FW = fresh weight. Data represent the average of three independent experiments, with $n=7$ per treatment per experiment. Statistical analysis was done using a two-way analysis of variance followed by Tukey's honestly significant difference test on the least square means $(\alpha=0.05)$. Columns not connected by the same letter are significantly different. Error bars represent standard error of the mean. 
ENOD11 hyperinduction by salt is dependent

\section{on NF signaling and mimicked}

by rhizobial succinoglycan mutants.

Because salt hyperinduces ENOD11 only in the presence of rhizobium, we tested whether the hyperinduction requires NF signaling or a different rhizobial signal. We inoculated seedlings with the SL44 mutant containing a deletion of $\operatorname{nod} A, \operatorname{nodB}, \operatorname{nod} C$, and part of $\operatorname{nodD}(\triangle(\operatorname{nod} D 1-A B C))$ that is unable to make NF (Fisher et al. 1988). None of the control seedlings inoculated with $\triangle($ nodD1-ABC) showed any ENOD11 expression, consistent with published work (Mitra et al. 2004b), nor did the salt-treated seedlings, establishing the requirement of NF in salt-regulation of ENOD11 induction (Fig. 6). Similarly, we found that dmi3 mutants, which are defective in NF signaling, also showed no symbiotic ENOD11 expression in control or salt stress conditions (Supplementary Fig. S6), indicating that salt requires NF signaling to activate ENOD11 expression.

Rhizobial EPS are also required for development of the rhizobium-legume symbiosis, particularly for infection. In S. meliloti, succinoglycan is required for the initiation of the IT in the root hair (Cheng and Walker 1998). To test whether surface EPS plays a role in ENOD11 hyperinduction, we inoculated plants with an $S$. meliloti exoY mutant both with and without salt stress. We observed a 16-fold higher expression of ENOD11 inoculated with the exoY mutant compared with the wild-type under the control condition, consistent with the similar infection phenotypes of salt-stressed and exoY-inoculated plants (Fig. 7).

Hyperinduction of ENOD11 by salt requires NF signaling in the presence of the wild-type, EPS-producing rhizobia (Fig. 6). To test whether ENOD11 hyperinduction by the exoY mutant also requires activation by the NF signaling cascade, we created an exoY $\Delta($ nodD1-ABC) double mutant (RFF1035), and found that, in the absence of NF signaling, ENOD11 was not expressed in either the control or salt-stressed conditions whether or not the exoY mutation was present (Fig. 7), in line with previous findings that the role of succinoglycan in regulating the rhizobium-legume symbiosis follows NF perception (Dickstein et al. 1988; Yang et al. 1992).

ENOD11 hyperinduction with the exoY mutant could be due to either the absence of succinoglycan or to the shunting of succinoglycan precursors to a different pathway. To test whether the deregulated ENOD11 expression is due to the absence of succinoglycan, we inoculated control or salt-stressed seedlings with the exoS96 mutant. The exoS gene functions in a regulatory network that controls expression of the exo genes and likely controls other sets of genes as well. The exoS96 mutants overproduce succinoglycan, and are also unable to infect plant roots (Cheng and Walker 1998). We observed a sixfold to sevenfold increase in ENOD11 expression with the exoS mutant compared with the exoY mutant in both the control and salt-stressed roots, and this hyperinduced expression pattern was maintained upon coinoculation with a 1:1 ratio of exoS to exoY. As with exoY, there was no significant difference between ENOD11 expression in the control and the salt-stressed conditions with either exoS or exoY/exoS coinoculation (Fig. 7). These results indicate that altered succinoglycan levels on infecting rhizobia are associated with ENOD11 hyperinduction. The observation that the hyperinduction of ENOD11 by exoY or exoS mutants and hyperinduction by salt stress is not additive suggests that succinoglycan and salt stress may function in a common pathway to regulate ENOD11 gene expression.

\section{NSP2 regulates genes symbiotically hyperinduced by salinity.}

Given the requirement of NF to activate symbiotic ENOD11 expression, salt must intersect with the pathway downstream of DMI3. Initially, ENOD11 was shown to be directly regulated by
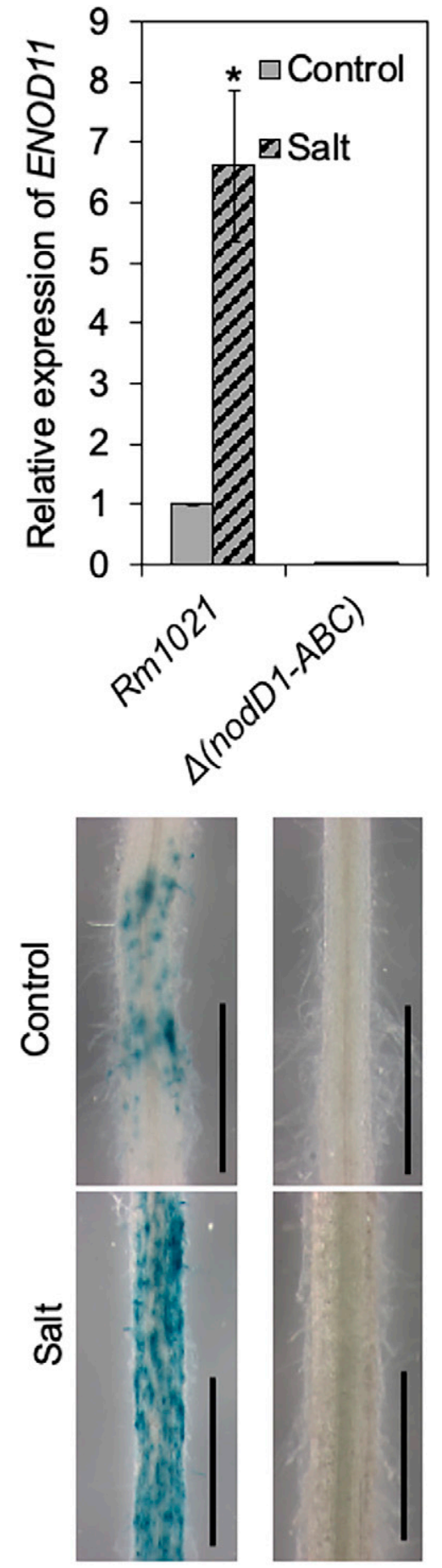

Fig. 6. Nod factor is required for early nodulin 11 (ENOD11) hyperinduction. ENOD11 expression in control or salt-stressed roots inoculated with wild-type Sinorhizobium meliloti (Rm1021) or the Nod-factor-deficient SL44 $(\triangle(\operatorname{nod} D 1-A B C))$ strain at 1 day postinoculation. The graph represents relative expression of ENOD11 based on quantitative reverse-transcription PCR, and representative images of pENOD11::uidA stained roots from plants grown in the different treatments are shown below. Relative expression was analyzed using a two-way analysis of variance followed by $t$ test on the least square means $(\alpha=0.05)$ on two representative independent experiments of three, with $n=7$ seedlings per treatment per experiment for each strain. The third experiment was excluded from the analysis because the consistent pattern of salt hyperinduction of ENOD11 was not observed in the roots of seedlings inoculated with the wild-type rhizobia in this experiment. Images of $p E N O D 11::$ uidA-stained roots are representative of three independent experiments, with $n=7$ seedlings per treatment per experiment for each strain. An asterisk $\left(^{*}\right)$ indicates a significant difference between treatments within a genotype. Error bars represent standard error of the mean. Scale bar $=1 \mathrm{~mm}$. 
the transcription factors NIN, ERN1, and NSP1-NSP2, although, subsequently, ENOD11 expression in root hairs was shown not to be dependent on ERN1 or NIN (Cerri et al. 2012; Liu et al. 2019; Vernié et al. 2015). We studied ENOD11 expression in the nin, ern 1, and nsp 2 mutants to determine whether the hyperinduction requires the function of one or more of these genes (Fig. 8). Although the hyperinduction was maintained in the nin-1 and ern 1-2 mutants (Fig. 8A and B), it was lost in the nsp2-2 mutant (Fig. 8C), indicating that NSP2 function is required for ENOD11 hyperinduction by salinity. Curiously, we noticed that ENOD11 expression in the control condition in the nsp2-2 mutant was not negligible, as previously reported (Marsh et al. 2007; Oldroyd and Long 2003) (Fig. 8C). As validation, we confirmed that the nsp2-2 mutant used in our experiments contains a 0.5-kb deletion in NSP2 (Kaló et al. 2005) (Supplementary Fig. S7). Thus, our work raises the possibility that NSP2 might play an inhibitory role in ENOD11 expression that is revealed only under certain growth conditions. In line with previous findings, we further observed that ENOD11 expression levels between the wild-type and the nin- 1 mutant in the absence of any salt stress are also comparable (Liu et al. 2019).

Genes with similar expression patterns are likely to be coregulated by a common factor. To determine whether $M t N P L$ and $M t D E F$, genes whose expression was among those most strongly hyperinduced by salt, are regulated by NSP2 as well, we studied their expression in the nsp2-2 mutant. Similar to ENOD11, the hyperinduction of $M t N P L$ was abolished in the nsp2-2 mutant, indicating that NSP2 regulates the hyperinduction of MtNPL (Fig. 8D). Although we observed a higher expression of $M t D E F$ in wild-type roots in the presence of salinity compared with control roots, the difference was not statistically significant. Similarly, in the nsp2-2 mutant, very little MtDEF expression was observed compared with the control but the difference was not significant

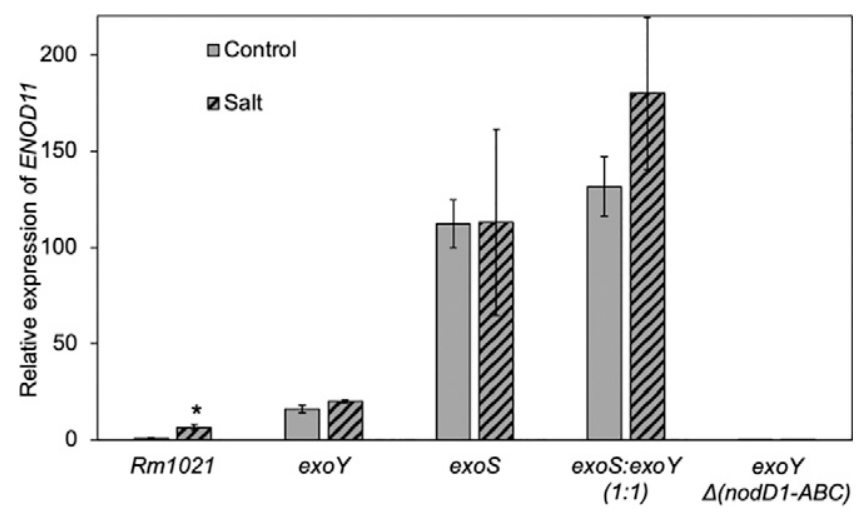

Fig. 7. Early nodulin 11 (ENOD11) hyperinduction by salt is mimicked by exo mutants. ENOD11 transcript abundance in control or salt-stressed roots 1 day after inoculating with wild-type Sinorhizobium meliloti (Rm1021), the exoY210 succinoglycan-defective mutant, the exoS96 succinoglycanoverproducing mutant, coinoculation with exoS:exoY (1:1), or inoculation with RFF1035, which contains both the exoY210 mutation and the deletion of the common nod region (exoY $\triangle(\operatorname{nodD} 1-A B C))$. Statistical analysis was done using a two-way analysis of variance (ANOVA) followed by $t$ test on the least square means $(\alpha=0.05)$ on two representative experiments of three, with $n=7$ seedlings per treatment per biological replicate for each strain. The third experiment was excluded from the analysis because the consistent pattern of salt hyperinduction of ENOD11 was not observed in the roots of seedlings inoculated with the wild-type rhizobia in this experiment (root tissue). An asterisk (*) indicates a significant difference between treatments within a genotype. ENOD11 expression in control roots inoculated with all of the mutants was also significantly different from the wild-type rhizobia (two-way ANOVA followed by $t$ test on the least square means, $\alpha=0.05$ ). Error bars represent standard error of the mean.
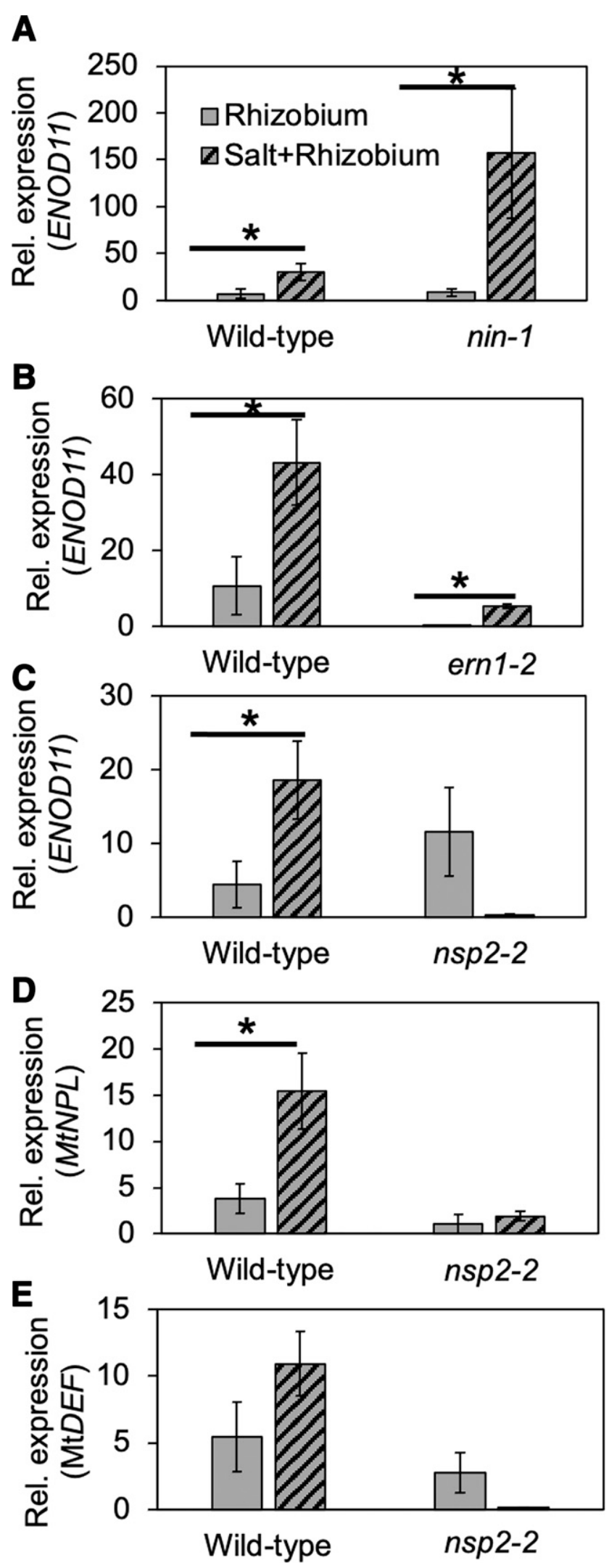

Fig. 8. NSP2 regulates genes symbiotically hyperinduced by salinity. ENOD11, MtNPL, and DEF expression in roots inoculated with Rm1021 at 1 day postinoculation in the wild-type or mutant $\mathbf{A}, \operatorname{nin}-1 ; \mathbf{B}$, ern 1-2; or $\mathbf{C}$ to $\mathbf{E}, n s p 2-2$ background in the presence or absence of $100 \mathrm{mM}$ $\mathrm{NaCl}$. Columns represent mean \pm standard error of the mean. Statistical analysis done with a $t$-test within a genotype $(\alpha=0.05)$. An asterisk $\left(^{*}\right)$ indicates a significant difference. Results from three independent experiments with $n=21$ seedlings total per treatment per genotype. 
(Fig. 8E). Combined, our results are consistent with NSP2 as the mediator of salt hyperinduction of symbiotic genes.

\section{Salt stress inhibits rhizobial infection in the epidermis.}

Because ENOD11 accumulates in the infection chamber in the root hair prior to the formation of an IT (Fournier et al. 2015), we tested whether ENOD11 hyperinduction by salt correlates with an increased rhizobial infection in salt-stressed roots. To this end, we used the rhizobial strain carrying the lac $Z$ gene under the constitutive hemA promoter to follow infection (Leong et al. 1985), comparing the number of infection events between control and salt-treated roots at $7 \mathrm{dpi}$. We chose this time point in order to capture progression of infection through the root hair, cortex, and nodule primordium. Contrary to our expectation, we found that the number of infection events that formed ITs in the root hair was significantly reduced under salt stress compared with the control (Fig. 9A), and was further reduced in the cortex (Fig. 9B). Few nodule primordia were made in salt-stressed plants (Fig. 9C) but the ones that were observed were infected with rhizobia (Fig. 9D). This observation indicates that salt interferes with the progression of infection in the root hair and cortex but suggests that, once rhizobia pass these stages, IT ramification in the nodule primordium can proceed.

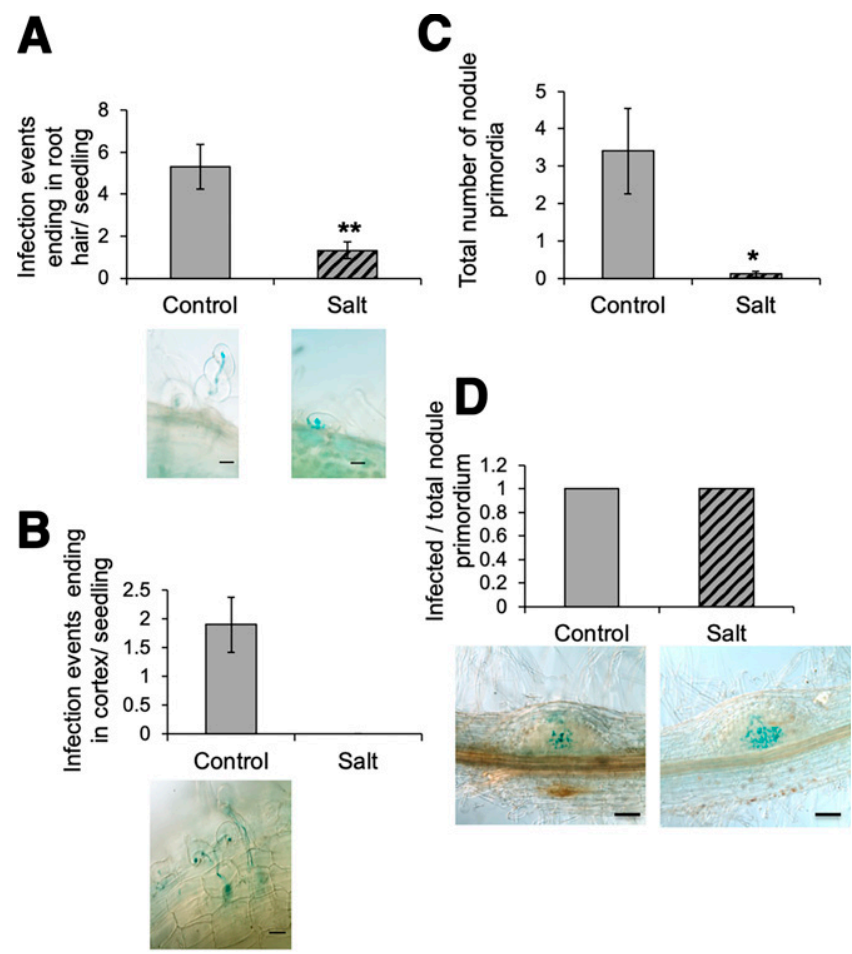

Fig. 9. Moderate salt stress inhibits rhizobial infection in the epidermis and cortex. Progression of rhizobial infection in roots grown with or without $100 \mathrm{mM} \mathrm{NaCl}$. Infection threads are monitored by inoculating with a hemA:lacZ-containing strain (Rm1021/pXLGD4) and staining for $\beta$-galactosidase activity at 7 days postinoculation. Graphs indicate number of infection events ending in $\mathbf{A}$, root hairs and $\mathbf{B}$, the cortex. Note that $\mathbf{C}$, very few nodule primordia are formed in salt-grown roots but $\mathbf{D}$, those that do form are infected (i.e., an average of 0.1 nodule primordia in 18 roots; all are infected). Representative images are shown below each graph. Data includes infection events where a clear end could be observed. Columns represent mean \pm standard error of the mean. Statistical analysis done with a $t$-test $(\alpha=0.05)$. Asterisks indicate a significant difference ${ }^{*}$ and ** denote $P<0.05$ and 0.005 , respectively). Results from three independent experiments with $n=18$ to 19 seedlings total per treatment. Scale bar $=10 \mu \mathrm{m}$ for infection in root hair and cortex and $50 \mu \mathrm{m}$ for infection in nodule primordium.

\section{DISCUSSION}

The nitrogen-fixing symbiosis between legumes and rhizobia is more sensitive to salt than the growth of either partner on its own. Here, we examined the effect of salt stress on early symbiotic signaling and rhizobium infection. We found that moderate salt stress primes the response of a set of early nodulation genes, including ENOD11, to rhizobium, stimulating early symbiotic signaling. Conversely, rhizobium inoculation antagonizes approximately $37 \%$ of salt-responsive genes, returning gene expression to control levels. We showed that the increased responsiveness to rhizobium is an early response to salt stress, mediated by the NSP2 transcription factor, and that, by $5 \mathrm{dpi}$, salt represses expression, coincident with a rise in ABA levels. Curiously, inoculation with exoY or exoS mutants phenocopies salt hyperinduction of early symbiotic ENOD11 expression, suggesting a link between EPS and salt stress. Finally, we identified a set of genes associated with nodulation only during salt stress, providing a window into the physiological changes needed to make nodulation work in an adverse environment. Together, our data reveal a complex interplay between the abiotic environment, the rhizobial endosymbiont, and its plant host.

\section{A moderate salt stress enhances the induction of a large number of early symbiotic genes.}

As our climate warms, drying soil leads to increased concentration of salts, a problem exacerbated by irrigation (Pimentel et al. 2004; Sherwood and Fu 2014). As a result, many plants routinely experience moderate salt stress. Under a mild to moderate stress, growth still happens but the plant must alter its physiology to accommodate the stress, revealing the role of genes and pathways that function to alleviate its effects (Verslues 2017). We found that growing seedlings under moderate salt stress increases the expression of several early symbiotic genes induced by rhizobium. For some genes, this synergistic effect results in an induction of more than 100-fold, as was observed for CBS1 and the LRR receptor kinase Medtr6g036780. We found that this hyperinduction is due to either the ionic component of salt, not the osmotic, or the increase in chloride ions. In addition, we showed that the stimulation of rhizobium-induced gene expression by salt is not due to salt-induced expression, because salt alone is unable to induce gene expression (Figs. 3 and 4; Supplementary File S1). Not all early nodulation genes show salt enhancement of rhizobium induction; the set of rhizobium-induced genes in our study whose expression was enhanced by salt, passing our twofold cutoff, included a number of genes involved in infection and early signaling (RPG, VPY, CHIT5b, VRC2, NPL, and ENOD11) (Table 1). Genes whose induction by rhizobium is not affected by salt include genes involved in an organogenesis initiation module (NIN, NFYA-1, and LBD16) (Table 2).

A number of rhizobium-induced genes that did not appear in our rhizobium-inoculated set $(+\mathrm{R}-\mathrm{S})$ were induced enough to exceed our cutoff threshold when salt was added $(+R+S)$. This set included several genes that were CRE1-dependent, such as CLE13, expansin A1 (Medtr7g110990), and LYK10, indicating that salt did not block the cytokinin signaling pathway but, rather, enhanced expression of some of the genes (Supplementary File S1) (van Zeijl et al. 2015b). GA also plays a major role in early NF signaling and rhizobium infection, and we found four genes encoding GA biosynthetic and catabolic enzymes differentially expressed in response to salt or to rhizobium plus salt. In particular, we observed a strong increase in expression of Medtr3g088745, encoding the biosynthetic enzyme GA 20-oxidase 5/6 (GA20ox5/GA20ox6), and of Medtr4g074130, encoding the degradative enzyme GA2-oxidase 13 (GA2ox13), exclusively in our $+\mathrm{R}+\mathrm{S}$ dataset (Igielski and Kepczyńska 2017; Wang et al. 2020). Both of these genes are strongly induced 
(14-fold for GA2ox13 and 42-50-fold for GA20ox5/GA20ox6) but did not pass the cutoff for differential expression in our $+\mathrm{R}-\mathrm{S}$ dataset. The strong induction of these two GA enzymes mirrors the strong induction of both by NF seen in other studies (Damiani et al. 2016a; Jardinaud et al. 2016; van Zeijl et al. 2015b) and may reflect the complex role of GA during nodulation. This observation is consistent with the overall pattern we saw, in which moderate salt stress hyperinduces genes associated with early nodulation signaling.

The fact that 147 of the 314 genes differentially regulated by the combined treatment $(+\mathrm{R}+\mathrm{S})$ were previously identified as early rhizobium- or NF-induced in $M$. truncatula transcriptomes (Breakspear et al. 2014; Damiani et al. 2016a; Jardinaud et al. 2016; Larrainzar et al. 2015; van Zeijl et al. 2015b) indicates that this synergistic effect of a moderate salt stress on early symbiotic gene expression has a large impact, affecting expression of most of the early symbiotic genes in our dataset and including both cytokinin-dependent and -independent pathways.

\section{Complex and dynamic interactions between the abiotic environment and the rhizobium-legume symbiosis.}

The arbuscular mycorrhizal symbiosis is known to confer resistance to drought and salinity in its hosts (Evelin et al. 2019; Kivlin et al. 2013). Our results show that expression of $37 \%$ of the saltregulated genes is restored to normal levels by rhizobium inoculation (Supplementary File S1). Thus, during the first day after inoculation, not only does salt influence the rhizobium-induced transcriptome but also the presence of rhizobia alters the salt-regulated transcriptome. Interestingly, genes known to be salt regulated that did not pass our threshold for differential gene expression in salt-treated roots were significantly repressed in roots treated with both salt and rhizobium. The transcription factor NAC969 regulates root architecture and nodulation and is known to be induced by $100 \mathrm{mM} \mathrm{NaCl}$ in roots (de Zélicourt et al. 2012). We found that NA969 is downregulated in the presence of salt and rhizobium, as is the LEA protein Medtr8g022990 and the germin Medtr8g020650, providing a further example of the repression of the salt response by rhizobial inoculation.

$\mathrm{NaCl}$ in the root environment interferes with $\mathrm{K}$ homeostasis (Assaha et al. 2017; Wu et al. 2018); thus, potassium deprivation can mimic the effects of salt stress by $\mathrm{NaCl}$. We observed only a modest $5.7 \%$ overlap between genes differentially regulated by salt stress and those detected under potassium deprivation (Supplementary File S1) by Garcia et al. (2017), likely due to differences in the age of the plants and growth conditions. However, we did find that several genes regulated by the combined $+\mathrm{R}+\mathrm{S}$ treatment were also detected in older roots experiencing potassium deprivation; interestingly, the directionality of expression was opposite for all genes shared between the two studies. These genes included several oxidative stress-responsive genes and the Medicago homo$\log$ of the Lotus EPSI receptor, EPR3 ( $L Y K 10$ ). It is tempting to speculate that this action by rhizobia may ameliorate some of the negative effects of moderate salt stress.

In order to survive, a plant must continuously assess its environment and adjust its resource allocation in response. An immediate response to a new stress is replaced by a different set of responses when the stress persists, requiring different physiological solutions and substantially altering the transcriptome (Yang et al. 2014) In our experiment, at the time of inoculation, plants only experienced stress for 4 days, and that stress was only moderate, allowing root and shoot growth to proceed normally. We speculate that, at this early timepoint, short-term stress responses enhance the plant's efforts to maintain growth and development but that, after five additional days of stress, harsher measures are implemented, reducing allocation of resources to any nonessential processes. Under conditions of extended stress, inhibiting nodulation is likely beneficial, to allow conservation of resources for plant growth and stress resistance. At this later time point, the combined effect of salt and rhizobia induce ABA accumulation to levels higher than either alone (Fig. 5). ABA is known to inhibit nodulation, altering calcium spiking and reducing symbiotic gene expression and rhizobium infection (Ding et al. 2008; Suzuki et al. 2004). At this stage, salt stress and rhizobia work additively, as opposed to the antagonistic effect of rhizobium on salt-regulated gene expression and the synergistic effect of salt and rhizobium we observed on early symbiotic gene expression. It will be interesting to explore the mechanism by which salt stress signaling and nodule development interact at this later stage in the symbiosis.

\section{NSP2 as a node integrating environmental and symbiotic signals.}

Plant response to external cues is coordinated through a suite of transcriptional regulators (Dietz et al. 2010). AP2/ERF, bZIP, NAC, and WRKY transcription factors function in communicating with environmental signals such as drought and salt stress, leading to an appropriate cellular response, and are often found at the point of integration in a signaling hub (Dietz et al. 2010; Golldack et al. 2011). Several transcription factors have been shown to participate in salt stress responses in M. truncatula roots (Ariel et al. 2010; Gruber et al. 2009; Merchan et al. 2003). The transcriptional regulation of ENOD11 by salt made us explore salt regulation of its upstream regulators. The GRAS transcription factor NSP2 plays an important role in NF signaling and rhizobial infection, and transcriptionally regulates ENOD11 (Cerri et al. 2012). In rice, the GRAS transcription factor OsGRAS23 is involved in drought and oxidative stress (Xu et al. 2015) and, in M. truncatula, several GRAS genes have been suggested to be involved in stress responses (Zhang et al. 2017). We found that salt stimulation of rhizobium-induced ENOD11 and NPL expression requires NSP2 function but not the function of other NF signaling network transcription factors such as ERN1 and NIN (Fig. 8). In L. japonicus, $N P L$ is downregulated in the nin and nspl mutants and NIN directly regulates $N P L$ expression and, in M. truncatula, NIN-regulated NPL expression is required for rhizobial infection whereas ENOD11 expression is independent of NIN function (Liu et al. 2019; Xie et al. 2012). Our study revealed that both ENOD11 and NPL require NSP2 for hyperinduction, which places NSP2 as the integrator of salt stress and symbiosis.

Environmental stress triggers rapid cellular changes such as increases in calcium and reactive oxygen species (ROS), which function as secondary signals to regulate gene expression (Gilroy et al. 2016; Noctor et al. 2014) ROS play crucial roles in both salt stress and the rhizobium-legume symbiosis (Damiani et al. 2016b; Hossain and Dietz 2016). Concurrent with the role of ROS in salinity and symbiosis, several rhizobium-induced genes hyperinduced by salt stress have been shown to require ROS for induction (Andrio et al. 2013). ENOD11, the gene most strongly hyperinduced by salt in our study, is one of the three genes most strongly inhibited when ROS production is reduced; however, several other genes we identified as being hyperinduced by salt, such as $V P Y, R P G$, SPII, NPL, and VRC2, also require ROS for induction (Andrio et al. 2013) (Supplementary File S1). Interestingly, some of the genes that were upregulated exclusively in our $+\mathrm{R}+\mathrm{S}$ cotreatment but had previously been shown to be induced by rhizobium or NF also require ROS for induction. This includes some of the genes most strongly upregulated in the rhizobium and salt stress cotreatment: CBS1, an MtN21/EamA-like transporter family protein (Medtr3g012420), a caffeic acid O-methyltransferase (Medtr3g021440), ENOD12, and SINA (Andrio et al. 2013). The requirement of both ROS and NSP2 for the hyperinduction of both NPL and ENOD11 raise the possibility that NSP2 may respond to an ROS signal downstream of salt.

This function of NSP2 as a node that responds to both NF signaling and environmental conditions is consistent with its role in 
the regulation of the strigolactone synthesis gene, D27. NSP2 and NSP1 regulate $D 27$ expression via the NF pathway in high phosphate but via an NF-independent pathway in low phosphate, indicating that NSP2 can respond to a second input (low environmental phosphate levels) distinct from NF signaling (Liu et al. 2011; van Zeijl et al. 2015a). Studies in Arabidopsis find that low phosphate levels in the environment trigger an increase in ROS levels in the root tip, which likely also mediates transcriptional changes (Balzergue et al. 2017; He et al. 2018; Shin et al. 2005). Together, these findings place NSP2 as an integrator of abiotic and biotic signals and suggest that NSP2 may respond to a common secondary signal such as ROS shared by different abiotic stress response pathways.

Interestingly, moderate salt stress represses NSP2 expression in the root, and rhizobium reverses this, restoring NSP2 to wild-type levels (Supplementary File S1). This ability of rhizobium to counteract the effect of salt stress suggests that rhizobium may modulate the plant salt response to benefit the symbiosis and indicates a more complex set of feedbacks between environment, plant, and microbe.

\section{Salt stress at the host-symbiont interface.}

Salt stress causes increased accumulation of amino acids, polyamines, and amino acid derivatives in plants (Alcázar et al. 2006; Trinchant et al. 2004; Verbruggen and Hermans 2008). We have previously observed increased accumulation of arginine in 14-dpi nodules from plants grown under moderate salt stress (Keller et al. 2018). In the present study, we observed downregulation of Medtr3g114870, annotated as ornithine decarboxylase (ODC), in salt-stressed roots $(-\mathrm{R}+\mathrm{S}$ versus $-\mathrm{R}-\mathrm{S})$. Arginine and ornithine are substrates in the polyamine synthesis pathway, in which ODC converts ornithine to the polyamine putrescine, which can then be converted to other polyamines. In addition to protecting against salt stress in both plants and bacteria, polyamines in $S$. meliloti 1021 appear to regulate EPS production, which is required for infection of the plant root (Becerra-Rivera and Dunn 2019; Chen et al. 2019). The reduced ODC expression in salt-stressed roots could alter polyamine levels in the plant and, thus, rhizobial EPS production in the rhizosphere or IT, affecting infection of the host root. Interestingly, ODC Medtr3g4114870 is one of the saltregulated genes whose repression is reversed by rhizobium inoculation, providing a specific example of rhizobia interacting with their plant host to modify the plant salt response to potentially benefit the symbiosis.

Although free-living Rm1021 can survive in the presence of salinity as high as $400 \mathrm{mM} \mathrm{NaCl}$ (Domínguez-Ferreras et al. 2006), salt stress might affect rhizobial physiology ex planta in a way that influences rhizobium-legume symbiosis. Salt stress induces nod genes independent of flavonoids in the halotolerant Rhizobium tropici CIAT899 (del Cerro et al. 2017; Guasch-Vidal et al. 2013; Pérez-Montaño et al. 2016). Furthermore, there is a strong overlap between genes upregulated by the flavonoid apigenin and by salinity in CIAT899 (Pérez-Montaño et al. 2016). In $S$. meliloti, osmotic stress promotes biofilm formation and the core nodDIABC genes are required to establish the three-dimensional architecture of biofilm (Fujishige et al. 2008; Rinaudi et al. 2006). In contrast, an inhibitory effect of salinity on nod gene expression has been suggested in R. tibeticum, which is alleviated by the flavonoids apigenin and hesperitin (Abd-Alla et al. 2014). It is possible that hyperinduction of early nodulation genes by 100 $\mathrm{mM} \mathrm{NaCl}$ that we observed is due to increased nod gene expression in S. meliloti, similar to CIAT899, which leads to increased production of NF.

EPS on the rhizobial surface plays an important role in resilience in the face of environmental stress but also plays an essential role in infection of the plant host root (Cheng and Walker 1998; Janczarek 2011). Increased salt in the environment promotes the production of EPS on the surface of S. meliloti and protects the bacterium against deleterious effects of ROS (Lehman and Long 2013). The $S$. meliloti exoY gene is required for synthesis of the EPSI molecule, succinoglycan, and exoY-defective mutants are able to initiate infection but are blocked in the root hair. In L. japonicus, EPS acts as a signal molecule, binding the EPR3 receptor, which distinguishes compatible and incompatible EPS molecules; however, the M. truncatula EPR3 homolog, LYK10, does not appear to have this function (Kawaharada et al. 2015; Maillet et al. 2020).

The relationship between salt, EPS, and ENOD11 is curious. Reducing exoY function increases ENOD11 expression, indicating that a functional exoY gene must normally limit ENOD11 expression. Yet adding salt when inoculating with an exoY mutant does not further induce ENOD11 expression, suggesting that exoY and salt function in the same pathway. If salt stimulates ENOD11 induction and wild-type exoY inhibits it, the simplest model is that salt inhibits succinoglycan signaling. However, salt actually increases the production of both exoY and succinoglycan (Breedveld et al. 1990; Rüberg et al. 2003). Therefore, if salt inhibits succinoglycan signaling, it is not at the level of production, and must be downstream. Succinoglycan binds cations and EPS viscosity is thought to be affected by side chains and, probably, cation binding (Breedveld et al. 1990; Hawkins and Oresnik 2017; Sutherland 1997). Because $100 \mathrm{mM} \mathrm{NaCl}$ interferes with succinoglycan binding to the antimicrobial NCR247 peptide (Arnold et al. 2018), it could also potentially affect interactions of succinoglycan with other molecules during infection. Interestingly, exoA mutants also appear to enhance ENOD11 induction (Mitra et al. 2004b), indicating that this may be a common effect of altering EPS structure or levels. It will be interesting to see whether the hyperinduction of ENOD11 expression by both EPS defects and salt treatment reflect a shared pathway or are the result of distinct mechanisms.

Additionally, inoculation with the exoY mutant causes an increased expression of defense-related genes in the host (Jones et al. 2008). Our KEGG pathway enrichment analyses revealed an overrepresentation of the phenylpropanoid biosynthesis pathway, alluding to the possibility that salt-stressed plants employ genes involved in defense responses to inhibit allocation of limited resources into developing a nodule (Fig. 2).

\section{A distinct set of accessory genes associated with nodulation under stress conditions.}

The rhizobium-legume symbiosis is generally studied under ideal conditions in a controlled laboratory setting. These studies have led to the identification of a core set of plant nodulation genes that are robustly associated with nodule initiation and development and required for their function. However, natural conditions are far from ideal. Are there nodulation genes required under different environmental conditions that we miss when abiotic stress is eliminated from the environment? We designed this RNA-seq experiment to explicitly look for an accessory set of genes associated with nodulation under moderate salt stress, a common problem in agricultural settings. We found 314 genes that were differentially expressed exclusively in roots exposed to salt and rhizobium. Of those, 167 genes, several of which were upregulated, had never been identified in transcriptomes of nodules or inoculated roots. Could these genes be playing a negative role in symbiosis? Overexpressing one or more of these genes and studying nodulation phenotype in the absence of salt stress could address this question. Among the unique genes, we found a number of genes involved in detoxification or defense. We also found a number of genes involved in the proteasome and ubiquitination such as SINA, PUB64, several genes encoding F-box proteins, and other E3 ubiquitin ligases, indicating the importance of regulation at the level of protein accumulation. The U-box containing PUB proteins was induced in response to a number of environmental stresses in 
M. truncatula (Song et al. 2017). With the new finding that DMI2 is stabilized after rhizobium inoculation (Pan et al. 2018), it is clear that protein stabilization and destruction plays an important role in regulation of nodulation.

The core set of nodulation genes is important but, most likely, the core set never functions alone but, instead, functions with different accessory gene sets used for different environmental conditions. Thus, in the natural environment, it is the interplay of those core genes with the accessory set that establishes the symbiosis. If so, the nodulation accessory set genes should be important for plant success in different environments. In fact, genes identified in genome-wide studies for genes with signatures of local adaptation (i.e., genetic changes in populations associated with specific climatic conditions or geographic regions) were also part of our set of genes differentially expressed exclusively when plants were inoculated with rhizobium in the presence of salt (Supplementary File S1). Medtr5g019070 is of particular interest, because it is induced 40-fold when both salt and rhizobium are present and was strongly associated with two climate temperature variables often linked to drier climates (Yoder et al. 2014), suggesting a possible role in the interaction between abiotic and biotic signaling in the root. Additionally, a candidate gene identified by Friesen and colleagues (2014) in their search for genes with alleles that sort with saline soils included a fusaric acid resistance-like protein (Medtr2g096670), shown to be downregulated in response to NF (van Zeijl et al. 2015b), which we also find to be downregulated in our $+\mathrm{R}+\mathrm{S}$ set of genes (Supplementary File S1).

A genome-wide study for candidate genes associated with different nodulation traits identified four genes from our $+\mathrm{R}+\mathrm{S}$ accessory gene set, all associated with nodule occupancy or location of nodulation on the root system (Stanton-Geddes et al. 2013). Three of these genes were repressed in our dataset, including the putative GA transporter MtNPF3.1 (Medtr5g055000) (Tal et al. 2016), an LEA gene (Medtr8g022990), and the chaperone DNAJ 11-like gene; none of these had been previously identified as being nodulation-related. In contrast, the LOB domain protein Medtr5g075020 was induced more than twofold in our study and was upregulated as early as 3 or $4 \mathrm{~h}$ after NF treatment in others (Supplementary File S1). These genes are all linked to nodulation phenotypes via this genome-wide association study but only one (Medtr5g075020) had previously been identified as being regulated transcriptionally by NF or inoculation. Identifying them in our $+\mathrm{R}+\mathrm{S}$-only set of genes indicated that salt stress can increase the expression of genes known to be required later for nodulation but which may not usually be induced at early time points by rhizobium or at high levels.

Interestingly, there was very little overlap, if any, between the genes identified in these different genome-wide studies. However, genes from each study overlapped with our putative abiotic accessory gene set, indicating that our approach of looking for abioticspecific nodulation genes was successful in identifying a number of genes that appear to have been targets of local adaptation to different soil, saline, and climate conditions. These findings also demonstrate a strong link between environmental stress, soil conditions, and nodulation. Most of these genes identified in population-wide studies were found by virtue of their association with either stress or nodulation. Our study, which explicitly examined nodulation under salt stress conditions that permit relatively normal levels of growth, revealed a role for these genes in nodulation under stress conditions. This connection suggests that nodulation genes may be under selection in dry, saline, or hot areas, and that the process of nodulation can be adjusted for success under many different environmental conditions. The very small overlap between these genome-wide studies suggests that there are different sets of accessory genes for different conditions and, also, that there are many accessory genes yet to find.
Together, our data paint a picture in which salt stress primes the response of rhizobium-induced genes to NF, stimulating early symbiotic signaling under salt stress and inducing an accessory set of genes involved in detoxification, biotic stress, and signaling. The importance of these genes to plant success can be seen by their identification in screens for genes that have signatures of local adaptation. We showed that NSP2 functions as a node to integrate $\mathrm{NF}$ and salt signals, coordinating symbiosis with environmental conditions. In addition, we found that rhizobium inoculation reverses much of the salt-responsive changes in gene expression, providing a possible mechanism for the observation that rhizobium inoculation can ameliorate effects of salt stress. Finally, our findings provide insight into the dynamic interplay between salt stress and the rhizobium-legume interaction and the molecular changes that occur in salt-stressed roots as they respond to rhizobium. Our findings lay the foundation for further analysis of the interaction between host, microbe, and environment at a mechanistic level.

\section{MATERIALS AND METHODS}

\section{Plant growth conditions.}

All experiments were performed using $M$. truncatula Jemalong A17. Seed were scarified in concentrated sulfuric acid for $15 \mathrm{~min}$, surface sterilized with $30 \%$ bleach for $10 \mathrm{~min}$, and imbibed for 4 to $6 \mathrm{~h}$ at room temperature. Imbibed seed were stratified at $4^{\circ} \mathrm{C}$ for 1 to 4 days or germinated immediately. Stratified seed were germinated overnight in in the dark. Germinated seedlings were placed in CYG seed germination pouches, in $10 \mathrm{ml}$ of buffered nodulation medium (Ehrhardt et al. 1992) supplemented with $1 \mathrm{mM}$ $\mathrm{KCl}$, referred to here as modified nodulation medium (MNM). We observed a significant increase in the number of nodules in pouch-grown seedlings in MNM. Seven seedlings were planted per pouch. The lower portions of the pouches were wrapped with aluminum foil to shade the roots. Well-spaced pouches were placed in a Styrofoam box, with a transparent lid, and the box was taped closed to prevent dehydration. Two watersaturated empty pouches were used to flank the remaining pouches, to prevent partial drying out of the pouches placed at the ends. The boxes were placed in MTR30 Conviron growth chambers, set at $20^{\circ} \mathrm{C}, 50 \%$ humidity, and a cycle of $16 \mathrm{~h}$ of light and $8 \mathrm{~h}$ of darkness, with an intensity of $100 \mu \mathrm{E} \mathrm{m}^{-2} \mathrm{~s}^{-1}$. Media were replenished twice a week; to maintain salt concentration, excess medium was poured out and fresh medium added to the pouch, pipetting onto the paper. All experiments were performed using 7 to 21 roots per treatment per replicate. Unless otherwise noted, the data shown are the average of three biological replicates. The exact number of roots used is noted in the respective figure legends.

\section{Rhizobial strains and inoculation.}

All rhizobial strains used are in the $S$. meliloti (Rm1021) background (Meade et al. 1982) and are listed in Supplementary Table S3. Pelleted cells from overnight cultures grown in low-salt LuriaBertani (LB) medium, containing half the amount $(85.5 \mathrm{mM})$ of $\mathrm{NaCl}$ present in regular LB medium (Bertani 1951) and supplemented with appropriate antibiotics, were resuspended in 10 $\mathrm{mM} \mathrm{MgSO}$, and the optical density at $600 \mathrm{~nm}$ was adjusted to 0.07 . Each pouch was inoculated with $1 \mathrm{ml}$ of the rhizobial suspension, or mock inoculated with the same volume of $10 \mathrm{mM} \mathrm{MgSO}_{4}$, added near the tip of the roots.

RNA extraction for transcriptome profiling and qRT-PCR.

Primary roots were frozen, ground in liquid nitrogen, and stored at $-80^{\circ} \mathrm{C}$. Total RNA was extracted from the ground tissue using the RNeasy Plant Mini kit (Qiagen), genomic DNA was removed using the TURBO DNA-free kit (Ambion), and the resulting RNA 
was further cleaned up using the RNeasy MinElute Clean-up kit (Qiagen). RNA quality was assessed with an Agilent 2100 Bioanalyzer, and RNA samples with RNA Integrity Number (RIN) values higher than 8 were processed further.

\section{RNA-seq.}

Twelve dual-indexed TruSeq stranded RNA-seq libraries were created for the four treatments from three biological replicates. The libraries were combined into a single pool and sequenced in a single lane of a HiSeq 2500 (Illumina) High Output, 125-bp paired-end run. Approximately 220 million pass filter reads for the lane were generated. All expected barcodes were detected. The mean quality scores were above Q30 for all libraries. The libraries were gel size selected to have average inserts of approximately $200 \mathrm{bp}$.

FastQ (125-bp) paired-end reads were trimmed using Trimmomatic (v 0.33) enabled with the "-q" option: 3-bp sliding-window trimming from the $3^{\prime}$ end requiring minimum Q30. Quality control checks on raw sequence data for each sample were performed with FastQC. Read mapping was performed via Tophat2 (v2.0.13) using the $M$. truncatula reference genome (4.0v2).

Gene quantification was done via Cuffquant for fragments per kilobase of exon model per million reads mapped values and feature counts for raw read counts. DEGs were identified using the edgeR (negative binomial) feature in CLCGWB (Qiagen) using raw read counts. The generated list was filtered based on a minimum $2 \times$ absolute fold change and false discovery rate (FDR) corrected $P<0.05$

\section{GO enrichment analysis.}

GO annotation was downloaded from the $M$. truncatula Genome Database, which included 4,415 GO terms for 29,846 genes. DEGs were mapped to this dataset and $278 \mathrm{GO}$ terms were obtained for the 450 genes, and their ontology (biological process, molecular function, and cellular component) distribution was summarized and drawn by $\mathrm{R}$ package 3.6.0 (R Core Team 2013). GO term enrichment analysis was performed with Fisher's exact test and significant GO terms were reported.

\section{KEGG pathway enrichment analysis.}

Partek Genomics Suite (version 7, build 7.17.1222; Partek) was used to perform a KEGG pathway enrichment analysis for DEGs defined by a corrected $P$ value (FDR) of 0.05 and a fold change of 11.5 I from the following contrasts: 1 versus 3 (36 genes), 1 versus 2 (543 genes), and 1 versus 4 (1,020 genes). The enrichment analysis parameters were configured to use Fisher's exact test and to only consider pathways containing more than two genes. The resulting enriched KEGG pathways for each gene set were defined based on an enrichment score of three or an enrichment $P$ value $<0.05$

\section{qRT-PCR.}

cDNA was synthesized from $1 \mu \mathrm{g}$ of total RNA using iScript cDNA synthesis kit (Bio-Rad). For each round of cDNA synthesis, one reaction lacking reverse transcriptase was prepared as a control to test for genomic DNA contamination. qPCR was performed with SYBR green (Quanta PerfecTa) in a StepOnePlus real-time PCR system (Applied Biosystems) using the delta-delta cycle threshold (CT) method and a standard cycle. All samples were run in duplicate. The helicase and UBC9 genes were used as endogenous controls (Kakar et al. 2008). The geometric means of the expression of these two genes were used to normalize CT values of the target genes. All primers are listed in Supplementary Table S4.

\section{Construction of the exoY $\Delta(\operatorname{nodD1}-A B C)$ mutant.}

S. meliloti strain SL44 (Fisher et al. 1988) was grown on tryptone yeast extract medium supplemented with streptomycin $(500 \mu \mathrm{g} / \mathrm{ml})$ and neomycin $(50 \mu \mathrm{g} / \mathrm{ml})$, and transduced with a N3 phage lysate made on $S$. meliloti strain Rm7210Sp (Lehman and Long 2013); transductants were selected on LB supplemented with streptomycin $(500 \mu \mathrm{g} / \mathrm{ml})$, neomycin $(50 \mu \mathrm{g} / \mathrm{ml})$, and spectinomycin $(50 \mu \mathrm{g} / \mathrm{ml})$.

\section{Reporter gene expression and chlorophyll quantification.}

M. truncatula plants stably transformed with pENOD11:uidA (Journet et al. 2001) were stained for GUS activity as described by Oldroyd et al. (2001), omitting the fixation step. Expression of lac $Z$ was assessed as described by Boivin et al. (1990). Roots were observed under a Leica dissecting microscope (LeicaMZ8) for a wide field of vision or Olympus compound microscope (Olympus BX60) for a better spatial resolution. Chlorophyll quantification was performed as described by Lichtenthaler (1987).

\section{ABA extraction and quantification.}

ABA was extracted as described by Walker-Simmons (1987), with modifications from Liang et al. (2007). Briefly, ground and frozen tissue was suspended in extracting methanol $(2.5 \mathrm{mM}$ citric acid monohydrate and $0.5 \mathrm{mM}$ 2,6-di-tert-butyl-4-methylphenol in absolute methanol) at a ratio of $1 \mathrm{ml}$ of solution per $100 \mathrm{mg}$ of tissue and nutated at $4^{\circ} \mathrm{C}$ in darkness for $36 \mathrm{~h}$. Following centrifugation at $1,500 \times g$ at $4^{\circ} \mathrm{C}$ for $15 \mathrm{~min}$, the cell debris pellet was discarded and the supernatant was adjusted to $70 \%$ methanol. Supernatant was then passed through a conditioned (absolute methanol followed by deionized water) C18 column (Sep-Pak light C18 cartridge; WAT023501), frozen briefly at $-80^{\circ} \mathrm{C}$, and evaporated to dryness using a SpeedVac. The residue was resuspended in tris-buffered saline and stored at $-20^{\circ} \mathrm{C}$. $\mathrm{ABA}$ was quantified using competitive enzyme-linked immunosorbent assay (PDK09347/0096; Agdia), following the manufacturer's instructions. All reactions were done in duplicate.

\section{AUTHOR-RECOMMENDED INTERNET RESOURCE}

CYG seed germination pouches: https://mega-international.com

\section{ACKNOWLEDGMENTS}

We thank S. Long (Stanford University) for providing the rhizobial strains SL44 and Rm7210; M. Arnold and G. Walker (Massachusetts Institute of Technology) for providing the strain Rm7096; A. Becker (University of Minnesota Genomics Center) for generating the RNA-seq libraries; T. Delaney, S. Keller, J. Preston, and M. Tierney (University of Vermont) for their advice and generosity with the use of equipment; University of Vermont Advanced Genome Technologies Core for help with RNA quality assessment; J.-M. Ané (University of Wisconsin-Madison) for critical reading of the manuscript; A. Howard for statistical advice; and members of the Harris lab for suggestions and support.

\section{LITERATURE CITED}

Abd-Alla, M. H., El-Enany, A. W. E., Bagy, M. K., and Bashandy, S. R. 2014. Alleviating the inhibitory effect of salinity stress on nod gene expression in Rhizobium tibeticum-fenugreek (Trigonella foenum graecum) symbiosis by isoflavonoids treatment. J. Plant Interact. 9:275-284

Alcázar, R., Marco, F., Cuevas, J. C., Patron, M., Ferrando, A., Carrasco, P., Tiburcio, A. F., and Altabella, T. 2006. Involvement of polyamines in plant response to abiotic stress. Biotechnol. Lett. 28:1867-1876.

Andriankaja, A., Boisson-Dernier, A., Frances, L., Sauviac, L., Jauneau, A., Barker, D. G., and de Carvalho-Niebel, F. 2007. AP2-ERF transcription factors mediate Nod factor dependent Mt ENOD11 activation in root hairs via a novel cis-regulatory motif. Plant Cell 19:2866-2885.

Andrio, E., Marino, D., Marmeys, A., de Segonzac, M. D., Damiani, I., Genre, A., Huguet, S., Frendo, P., Puppo, A., and Pauly, N. 2013. 
Hydrogen peroxide-regulated genes in the Medicago truncatula-Sinorhizobium meliloti symbiosis. New Phytol. 198:179-189.

Ariel, F., Diet, A., Verdenaud, M., Gruber, V., Frugier, F., Chan, R., and Crespi, M. 2010. Environmental regulation of lateral root emergence in Medicago truncatula requires the HD-Zip I transcription factor HB1. Plant Cell 22:2171-2183.

Arnold, M. F. F., Penterman, J., Shabab, M., Chen, E. J., and Walker, G. C. 2018. Important late stage symbiotic role of the Sinorhizobium meliloti exopolysaccharide succinoglycan. J. Bacteriol. 200:e00665-17.

Arrighi, J.-F., Godfroy, O., de Billy, F., Saurat, O., Jauneau, A., and Gough, C. 2008. The RPG gene of Medicago truncatula controls Rhizobiumdirected polar growth during infection. Proc. Natl. Acad. Sci. U.S.A. 105:9817-9822.

Assaha, D. V. M., Ueda, A., Saneoka, H., Al-Yahyai, R., and Yaish, M. W. 2017. The role of $\mathrm{Na}^{+}$and $\mathrm{K}^{+}$transporters in salt stress adaptation in glycophytes. Front. Physiol. 8:509.

Balzergue, C., Dartevelle, T., Godon, C., Laugier, E., Meisrimler, C., Teulon, J. M., Creff, A., Bissler, M., Brouchoud, C., Hagège, A., Müller, J., Chiarenza, S., Javot, H., Becuwe-Linka, N., David, P., Péret, B., Delannoy, E., Thibaud, M.-C., Armengaud, J., Abel, S., Pellequer, J.-L., Nussaume, L., and Desnos, T. 2017. Low phosphate activates STOP1-ALMT1 to rapidly inhibit root cell elongation. Nat. Commun. 8:15300.

Becerra-Rivera, V. A., and Dunn, M. F. 2019. Polyamine biosynthesis and biological roles in rhizobia. FEMS Microbiol. Lett. 366:fnz084.

Bertani, G. 1951. Studies on lysogenesis. I. The mode of phage liberation by lysogenic Escherichia coli. J. Bacteriol. 62:293-300.

Boivin, C., Camut, S., Malpica, C. A., Truchet, G., and Rosenberg, C. 1990. Rhizobium meliloti genes encoding catabolism of Trigonelline are induced under symbiotic conditions. Plant Cell 2:1157-1170.

Bonhomme, M., Boitard, S., Clemente, H. S., Dumas, B., Young, N., and Jacquet, C. 2015. Genomic signature of selective sweeps illuminates adaptation of Medicago truncatula to root-associated microorganisms. Mol. Biol. Evol. 32:2097-2110.

Borucki, W., and Sujkowska, M. 2008. The effects of sodium chloridesalinity upon growth, nodulation, and root nodule structure of pea (Pisum sativum L.) plants. Acta Physiol. Plant. 30:293-301.

Breakspear, A., Liu, C., Roy, S., Stacey, N., Rogers, C., Trick, M., Morieri, G., Mysore, K. S., Wen, J., Oldroyd, G. E. D., Downie, J. A., and Murray, J. D. 2014. The root hair "infectome" of Medicago truncatula uncovers changes in cell cycle genes and reveals a requirement for auxin signaling in rhizobial infection. Plant Cell 26:4680-4701.

Breedveld, M. W., Zevenhuizen, L. P. T. M., and Zehnder, A. J. B. B. 1990. Osmotically induced oligo- and polysaccharide synthesis by Rhizobium meliloti SU-47. J. Gen. Microbiol. 136:2511-2519.

Brenner, W. G., and Schmülling, T. 2012. Transcript profiling of cytokinin action in Arabidopsis roots and shoots discovers largely similar but also organ-specific responses. BMC Plant Biol. 12:112.

Cao, Y.-R., Chen, S.-Y., and Zhang, J.-S. 2008. Ethylene signaling regulates salt stress response. Plant Signal. Behav. 3:761-763.

Catoira, R. 2000. Four genes of Medicago truncatula controlling components of a Nod factor transduction pathway. Plant Cell 12:1647-1665.

Cerri, M. R., Frances, L., Laloum, T., Auriac, M.-C., Niebel, A., Oldroyd, G. E. D., Barker, D. G., Fournier, J., and de Carvalho-Niebel, F. 2012. Medicago truncatula ERN transcription factors: Regulatory interplay with NSP1/NSP2 GRAS factors and expression dynamics throughout rhizobial infection. Plant Physiol. 160:2155-2172.

Chakraborty, S. 2018. Intersection of salt signaling with nodule initiation and maturation during Medicago truncatula-Sinorhizobium meliloti symbiosis. Ph.D. dissertation, University of Vermont.

Chen, D., Shao, Q., Yin, L., Younis, A., and Zheng, B. 2019. Polyamine function in plants: Metabolism, regulation on development, and roles in abiotic stress responses. Front. Plant Sci. 9:1945.

Chen, T., Yang, Q., Zhang, X., Ding, W., and Gruber, M. 2012. An alfalfa (Medicago sativa L.) ethylene response factor gene, MsERF11, enhances salt tolerance in transgenic Arabidopsis. Plant Cell Rep. 31: 1737-1746.

Cheng, H. P., and Walker, G. C. 1998. Succinoglycan is required for initiation and elongation of infection threads during nodulation of alfalfa by Rhizobium meliloti. J. Bacteriol. 180:5183-5191.

Cordovilla, M. P., Ligero, F., and Lluch, C. 1994. The effect of salinity on $\mathrm{N}$ fixation and assimilation in Vicia faba. J. Exp. Bot. 45:1483-1488.

Damiani, I., Drain, A., Guichard, M., Balzergue, S., Boscari, A., Boyer, J.-C., Brunaud, V., Cottaz, S., Rancurel, C., Da Rocha, M., Fizames, C., Fort, S., Gaillard, I., Maillol, V., Danchin, E. G. J., Rouached, H., Samain, E., Su, Y.-H., Thouin, J., Touraine, B., Puppo, A., Frachisse, J.-M., Pauly, N., and Sentenac, H. 2016a. Nod Factor effects on root hair-specific transcriptome of Medicago truncatula: Focus on plasma membrane transport systems and reactive oxygen species networks. Front. Plant Sci. 7:794

Damiani, I., Pauly, N., Puppo, A., Brouquisse, R., and Boscari, A. 2016b. Reactive oxygen species and nitric oxide control early steps of the legume-Rhizobium symbiotic interaction. Front. Plant Sci. 7:454.

de Carvalho Niebel, F., Lescure, N., Cullimore, J. V., and Gamas, P. 1998. The Medicago truncatula MtAnn1 gene encoding an annexin is induced by Nod factors and during the symbiotic interaction with Rhizobium meliloti. Mol. Plant-Microbe Interact. 11:504-513.

del Cerro, P., Pérez-Montaño, F., Gil-Serrano, A., López-Baena, F. J., Megías, M., Hungria, M., and Ollero, F. J. 2017. The Rhizobium tropici CIAT 899 NodD2 protein regulates the production of Nod factors under salt stress in a flavonoid-independent manner. Sci. Rep. 7:46712.

de Lorenzo, L., Merchan, F., Blanchet, S., Megías, M., Frugier, F., Crespi, M., Sousa, C., Megias, M., Frugier, F., Crespi, M., and Sousa, C. 2007. Differential expression of the TFIIIA regulatory pathway in response to salt stress between Medicago truncatula genotypes. Plant Physiol. 145: 1521-1532.

de Lorenzo, L., Merchan, F., Laporte, P., Thompson, R., Clarke, J., Sousa, C., and Crespi, M. 2009. A novel plant leucine-rich repeat receptor kinase regulates the response of Medicago truncatula roots to salt stress. Plant Cell 21:668-680.

Den Herder, G., De Keyser, A., De Rycke, R., Rombauts, S., Van de Velde, W., Clemente, M. R., Verplancke, C., Mergaert, P., Kondorosi, E., Holsters, M., and Goormachtig, S. 2008. Seven in absentia proteins affect plant growth and nodulation in Medicago truncatula. Plant Physiol. 148:369-382.

de Zélicourt, A., Diet, A., Marion, J., Laffont, C., Ariel, F., Moison, M., Zahaf, O., Crespi, M., Gruber, V., and Frugier, F. 2012. Dual involvement of a Medicago truncatula NAC transcription factor in root abiotic stress response and symbiotic nodule senescence. Plant J. 70:220-230.

Dickstein, R., Bisseling, T., Reinhold, V. N., and Ausubel, F. M. 1988. Expression of nodule-specific genes in alfalfa root nodules blocked at an early stage of development. Genes Dev. 2:677-687.

Dietz, K. J., Vogel, M. O., and Viehhauser, A. 2010. AP2/EREBP transcription factors are part of gene regulatory networks and integrate metabolic, hormonal and environmental signals in stress acclimation and retrograde signalling. Protoplasma 245:3-14.

Ding, Y., Kalo, P., Yendrek, C., Sun, J., Liang, Y., Marsh, J. F., Harris, J. M., and Oldroyd, G. E. D. 2008. Abscisic acid coordinates Nod factor and cytokinin signaling during the regulation of nodulation in Medicago truncatula. Plant Cell 20:2681-2695.

Domínguez-Ferreras, A., Pérez-Arnedo, R., Becker, A., Olivares, J., Soto, M. J., and Sanjuán, J. 2006. Transcriptome profiling reveals the importance of plasmid pSymB for osmoadaptation of Sinorhizobium meliloti. J. Bacteriol. 188:7617-7625.

Duan, L., Dietrich, D., Ng, C. H., Chan, P. M., Bhalerao, R., Bennett, M. J., and Dinneny, J. R. 2013. Endodermal ABA signaling promotes lateral root quiescence during salt stress in Arabidopsis seedlings. Plant Cell 25:324-341.

Ehrhardt, D. W., Atkinson, E. M., and Long, S. R. 1992. Depolarization of alfalfa root hair membrane potential by Rhizobium meliloti Nod factors. Science 256:998-1000.

Esseling, J. J., Lhuissier, F. G. P., and Emons, A. M. C. 2003. Nod factorinduced root hair curling: Continuous polar growth towards the point of Nod factor application. Plant Physiol. 132:1982-1988.

Evelin, H., Devi, T. S., Gupta, S., and Kapoor, R. 2019. Mitigation of salinity stress in plants by arbuscular mycorrhizal symbiosis: Current understanding and new challenges. Front. Plant Sci. 10:470.

Ferguson, B. J., Indrasumunar, A., Hayashi, S., Lin, M. H., Lin, Y. H., Reid, D. E., and Gresshoff, P. M. 2010. Molecular analysis of legume nodule development and autoregulation. J. Integr. Plant Biol. 52:61-76.

Ferguson, B. J., and Mathesius, U. 2014. Phytohormone regulation of legume-rhizobia interactions. J. Chem. Ecol. 40:770-790.

Fisher, R. F., Egelhoff, T. T., Mulligan, J. T., and Long, S. R. 1988. Specific binding of proteins from Rhizobium meliloti cell-free-extracts containing NodD to DNA-sequences upstream of inducible nodulation genes. Genes Dev. 2:282-293.

Fliegmann, J., Jauneau, A., Pichereaux, C., Rosenberg, C., Gasciolli, V., Timmers, A. C. J., Burlet-Schiltz, O., Cullimore, J., and Bono, J. J. 2016. LYR3, a high-affinity LCO-binding protein of Medicago truncatula, interacts with LYK3, a key symbiotic receptor. FEBS Lett. 590: 1477-1487.

Fournier, J., Teillet, A., Chabaud, M., Ivanov, S., Genre, A., Limpens, E., de Carvalho-Niebel, F., and Barker, D. G. 2015. Remodeling of the infection chamber before infection thread formation reveals a two-step mechanism for rhizobial entry into the host legume root hair. Plant Physiol. 167:1233-1242. 
Fournier, J., Timmers, A. C. J., Sieberer, B. J., Jauneau, A., Chabaud, M., and Barker, D. G. 2008. Mechanism of infection thread elongation in root hairs of Medicago truncatula and dynamic interplay with associated rhizobial colonization. Plant Physiol. 148:1985-1995.

Friesen, M. L., von Wettberg, E. J., Badri, M., Moriuchi, K. S., Barhoumi, F., Chang, P. L., Cuellar-Ortiz, S., Cordeiro, M. A., Vu, W. T., Arraouadi, S., Djébali, N., Zribi, K., Badri, Y., Porter, S. S., Aouani, M. E., Cook, D. R., Strauss, S. Y., and Nuzhdin, S. V. 2014. The ecological genomic basis of salinity adaptation in Tunisian Medicago truncatula. BMC Genomics 15:1160.

Fujishige, N. A., Lum, M. R., De Hoff, P. L., Whitelegge, J. P., Faull, K. F., and Hirsch, A. M. 2008. Rhizobium common nod genes are required for biofilm formation. Mol. Microbiol. 67:504-515.

Gage, D. J. 2002. Analysis of infection thread development using Gfp- and DsRed-expressing Sinorhizobium meliloti. J. Bacteriol. 184:7042-7046.

Gage, D. J. 2004. Infection and invasion of roots by symbiotic, nitrogenfixing rhizobia during nodulation of temperate legumes. Microbiol. Mol. Biol. Rev. 68:280-300.

Garcia, K., Chasman, D., Roy, S., and Ané, J.-M. 2017. Physiological responses and gene co-expression network of mycorrhizal roots under $\mathrm{K}^{+}$deprivation. Plant Physiol. 173:1811-1823.

Gilroy, S., Białasek, M., Suzuki, N., Górecka, M., Devireddy, A. R. Karpiński, S., and Mittler, R. 2016. ROS, calcium, and electric signals: Key mediators of rapid systemic signaling in plants. Plant Physiol. 171: 1606-1615.

Golldack, D., Lüking, I., and Yang, O. 2011. Plant tolerance to drought and salinity: Stress regulating transcription factors and their functional significance in the cellular transcriptional network. Plant Cell Rep. 30: 1383-1391.

Graham, P. H. 2003. Legumes: Importance and constraints to greater use. Plant Physiol. 131:872-877.

Gruber, V., Blanchet, S., Diet, A., Zahaf, O., Boualem, A., Kakar, K., Alunni, B., Udvardi, M., Frugier, F., and Crespi, M. 2009. Identification of transcription factors involved in root apex responses to salt stress in Medicago truncatula. Mol. Genet. Genomics 281:55-66.

Guasch-Vidal, B., Estévez, J., Dardanelli, M. S., Soria-Díaz, M. E. Fernández de Córdoba, F., Balog, C. I. A., Manyani, H., Gil-Serrano, A., Thomas-Oates, J., Hensbergen, P. J., Deelder, A. M., Megías, M., and van Brussel, A. A. N. 2013. High $\mathrm{NaCl}$ concentrations induce the Nod genes of Rhizobium tropici CIAT899 in the absence of flavonoid inducers. Mol. Plant-Microbe Interact. 26:451-460.

Guerrero, J., Andrello, M., Burgarella, C., and Manel, S. 2018. Soil environment is a key driver of adaptation in Medicago truncatula: New insights from landscape genomics. New Phytol. 219:378-390.

HanumanthaRao, B., Nair, R. M., and Nayyar, H. 2016. Salinity and high temperature tolerance in mungbean [Vigna radiata $(\mathrm{L}$.$) Wilczek] from$ a physiological perspective. Front. Plant Sci. 7:957.

Hawkins, J. P., and Oresnik, I. J. 2017. Characterisation of a gene encoding a membrane protein that affects exopolysaccharide production and intracellular $\mathrm{Mg}^{2+}$ concentrations in Ensifer meliloti. FEMS Microbiol. Lett. 364:fnx061.

He, H., Van Breusegem, F., and Mhamdi, A. 2018. Redox-dependent control of nuclear transcription in plants. J. Exp. Bot. 69:3359-3372.

Hirsch, S., Kim, J., Munoz, A., Heckmann, A. B., Downie, J. A., and Oldroyd, G. E. D. 2009. GRAS proteins form a DNA binding complex to induce gene expression during nodulation signaling in Medicago truncatula. Plant Cell 21:545-557.

Hossain, M. S., and Dietz, K. J. 2016. Tuning of redox regulatory mechanisms, reactive oxygen species and redox homeostasis under salinity stress. Front. Plant Sci. 7:548.

Igielski, R., and Kepczyńska, E. 2017. Gene expression and metabolite profiling of gibberellin biosynthesis during induction of somatic embryogenesis in Medicago truncatula Gaertn. PLoS One 12:e0182055.

Janczarek, M. 2011. Environmental signals and regulatory pathways that influence exopolysaccharide production in rhizobia. Int. J. Mol. Sci. 12:7898-7933.

Jardinaud, M.-F., Boivin, S., Rodde, N., Catrice, O., Kisiala, A., Lepage, A., Moreau, S., Roux, B., Cottret, L., Sallet, E., Brault, M., Emery, R. J. N., Gouzy, J., Frugier, F., and Gamas, P. 2016. A laser dissection-RNAseq analysis highlights the activation of cytokinin pathways by Nod factors in the Medicago truncatula root epidermis. Plant Physiol. 171:2256-2276.

Jia, W. 2002. Salt-stress-induced ABA accumulation is more sensitively triggered in roots than in shoots. J. Exp. Bot. 53:2201-2206.

Jones, K. M., Kobayashi, H., Davies, B. W., Taga, M. E., and Walker, G. C. 2007. How rhizobial symbionts invade plants: The SinorhizobiumMedicago model. Nat. Rev. Microbiol. 5:619-633.

Jones, K. M., Sharopova, N., Lohar, D. P., Zhang, J. Q., VandenBosch, K. A., and Walker, G. C. 2008. Differential response of the plant
Medicago truncatula to its symbiont Sinorhizobium meliloti or an exopolysaccharide-deficient mutant. Proc. Natl. Acad. Sci. U.S.A. 105 704-709.

Journet, E. P., El-Gachtouli, N., Vernoud, V., de Billy, F., Pichon, M., Dedieu, A., Arnould, C., Morandi, D., Barker, D. G., and Gianinazzi-Pearson, V 2001. Medicago truncatula ENOD11: A novel RPRP-encoding early nodulin gene expressed during mycorrhization in arbuscule-containing cells. Mol. Plant-Microbe Interact. 14:737-748.

Journet, E. P., Pichon, M., Dedieu, A., De Billy, F., Truchet, G., and Barker, D. G. 1994. Rhizobium meliloti Nod factors elicit cell-specific transcription of the ENOD12 gene in transgenic alfalfa. Plant J. 6:241-249.

Kakar, K., Wandrey, M., Czechowski, T., Gaertner, T., Scheible, W.-R., Stitt, M., Torres-Jerez, I., Xiao, Y., Redman, J. C., Wu, H. C., Cheung, F., Town, D. C., and Udvardi, M. K. 2008. A community resource for high-throughput quantitative RT-PCR analysis of transcription factor gene expression in Medicago truncatula. Plant Methods 4:18

Kaló, P., Gleason, C., Edwards, A., Marsh, J., Mitra, R. M., Hirsch, S. Jakab, J., Sims, S., Long, S. R., Rogers, J., Kiss, G. B., Downie, J. A. and Oldroyd, G. E. D. 2005. Nodulation signaling in legumes requires NSP2, a member of the GRAS family of transcriptional regulators. Science 308:1786-1789.

Kawaharada, Y., Kelly, S., Nielsen, M. W., Hjuler, C. T., Gysel, K., Muszyński, A., Carlson, R. W., Thygesen, M. B., Sandal, N. Asmussen, M. H., Andersen, S. U., Krusell, L., Thirup, S., Jensen, K. J., Ronson, C. W., Blaise, M., Radutoiu, S., and Stougaard, J. 2015. Receptor-mediated exopolysaccharide perception controls bacterial infection. Nature 523:308-312.

Kawaharada, Y., Nielsen, M. W., Kelly, S., James, E. K., Andersen, K. R., Rasmussen, S. R., Füchtbauer, W., Madsen, L. H., Heckmann, A. B., Radutoiu, S., and Stougaard, J. 2017. Differential regulation of the Epr3 receptor coordinates membrane-restricted rhizobial colonization of root nodule primordia. Nat. Commun. 8:14534.

Keller, C., Maeda, J., Jayaraman, D., Chakraborty, S., Sussman, M. R., Harris, J., Ané, J.-M., and Li, L. 2018. Comparison of vacuum MALDI and AP-MALDI platforms for the mass spectrometry imaging of metabolites involved in salt stress in Medicago truncatula. Front. Plant Sci. 9:1238.

Kivlin, S. N., Emery, S. M., and Rudgers, J. A. 2013. Fungal symbionts alter plant responses to global change. Am. J. Bot. 100:1445-1457.

Kreps, J. A., Wu, Y., Chang, H. S., Zhu, T., Wang, X., and Harper, J. F. 2002. Transcriptome changes for Arabidopsis in response to salt, osmotic, and cold stress. Plant Physiol. 130:2129-2141.

Ku, Y. S., Sintaha, M., Cheung, M. Y., and Lam, H. M. 2018. Plant hormone signaling crosstalks between biotic and abiotic stress responses. Int. J. Mol. Sci. 19:3206

Laffont, C., De Cuyper, C., Fromentin, J., Mortier, V., De Keyser, A., Verplancke, C., Holsters, M., Goormachtig, S., and Frugier, F. 2018. MtNRLK1, a CLAVATA1-like leucine-rich repeat receptor-like kinase upregulated during nodulation in Medicago truncatula. Sci. Rep. 8:2046.

Laporte, P., Lepage, A., Fournier, J., Catrice, O., Moreau, S., Jardinaud, M. F., Mun, J. H., Larrainzar, E., Cook, D. R., Gamas, P., and Niebel, A. 2014. The CCAAT box-binding transcription factor NF-YA1 controls rhizobial infection. J. Exp. Bot. 65:481-494.

Larrainzar, E., Riely, B. K., Kim, S. C., Carrasquilla-Garcia, N., Yu, H.-J., Hwang, H.-J., Oh, M., Kim, G. B., Surendrarao, A. K., Chasman, D., Siahpirani, A. F., Penmetsa, R. V., Lee, G.-S., Kim, N., Roy, S., Mun, J.-H., and Cook, D. R. 2015. Deep sequencing of the Medicago truncatula root transcriptome reveals a massive and early interaction between nodulation factor and ethylene signals. Plant Physiol. 169:233-265.

Lehman, A. P., and Long, S. R. 2013. Exopolysaccharides from Sinorhizobium meliloti can protect against $\mathrm{H} 2 \mathrm{O} 2$-dependent damage. J. Bacteriol. 195:5362-5369.

Leong, S. A., Williams, P. H., and Ditta, G. S. 1985. Analysis of the $5^{\prime}$ regulatory region of the gene for delta-aminolevulinic acid synthetase of Rhizobium meliloti. Nucleic Acids Res. 13:5965-5976.

Li, D., Su, Z., Dong, J., and Wang, T. 2009. An expression database for roots of the model legume Medicago truncatula under salt stress. BMC Genomics 10:517.

Li, D., Zhang, Y., Hu, X., Shen, X., Ma, L., Su, Z., Wang, T., and Dong, J. 2011. Transcriptional profiling of Medicago truncatula under salt stress identified a novel CBF transcription factor MtCBF4 that plays an important role in abiotic stress responses. BMC Plant Biol. 11:109.

Liang, Y., Mitchell, D. M., and Harris, J. M. 2007. Abscisic acid rescues the root meristem defects of the Medicago truncatula latd mutant. Dev. Biol. 304:297-307

Lichtenthaler, H. K. 1987. Chlorophylls and carotenoids: Pigments of photosynthetic biomembranes. Methods Enzymol. 148:350-382.

Liu, C.-W., Breakspear, A., Guan, D., Cerri, M. R., Jackson, K., Jiang, S., Robson, F., Radhakrishnan, G. V., Roy, S., Bone, C., Stacey, N., Rogers, 
C., Trick, M., Niebel, A., Oldroyd, G. E. D., de Carvalho-Niebel, F., and Murray, J. D. 2019. NIN acts as a network hub controlling a growth module required for rhizobial infection. Plant Physiol. 179:1704-1722.

Liu, W., Kohlen, W., Lillo, A., den Camp, R. O., Ivanov, S., Hartog, M., Limpens, E., Jamil, M., Smaczniak, C., Kaufmann, K., Yang, W.-C., Hooiveld, G. J. E. J., Charnikhova, T., Bouwmeester, H. J., Bisseling, T., and Geurts, R. 2011. Strigolactone biosynthesis in Medicago truncatula and rice requires the symbiotic GRAS-type transcription factors NSP1 and $\mathrm{NSP}_{2}$. Plant Cell 23:3853-3865.

Luo, D., Wu, Y., Liu, J., Zhou, Q., Liu, W., Wang, Y., Yang, Q., Wang, Z., and Liu, Z. 2018. Comparative transcriptomic and physiological analyses of Medicago sativa L. Indicates that multiple regulatory networks are activated during continuous ABA treatment. Int. J. Mol. Sci. 20:47.

Maillet, F., Fournier, J., Mendis, H., Tadege, M., Wen, J., Ratet, P., Mysore, K., Gough, C., and Jones, K. 2020. Sinorhizobium meliloti succinylated high-molecular-weight succinoglycan and the Medicago truncatula LysM receptor-like kinase MtLYK10 participate independently in symbiotic infection. Plant J. 102:311-326.

Marsh, J. F., Rakocevic, A., Mitra, R. M., Brocard, L., Sun, J., Eschstruth, A., Long, S. R., Schultze, M., Ratet, P., and Oldroyd, G. E. D. 2007. Medicago truncatula NIN is essential for rhizobial-independent nodule organogenesis induced by autoactive calcium/calmodulin-dependent protein kinase. Plant Physiol. 144:324-335.

Meade, H. M., Long, S. R., Ruvkun, G. B., Brown, S. E., and Ausubel, F. M. 1982. Physical and genetic characterization of symbiotic and auxotrophic mutants of Rhizobium meliloti induced by transposon Tn5 mutagenesis. J. Bacteriol. 149:114-122.

Mens, C., Hastwell, A. H., Su, H., Gresshoff, P. M., Mathesius, U., and Ferguson, B. J. 2020. Characterisation of Medicago truncatula CLE34 and CLE35 in nitrate and rhizobia regulation of nodulation. New Phytol. 229:2525-2534.

Merchan, F., Breda, C., Hormaeche, J. P., Sousa, C., Kondorosi, A., Aguilar, O. M., Megias, M., and Crespi, M. 2003. A Krüppel-like transcription factor gene is involved in salt stress responses in Medicago spp. Plant Soil 257:1-9.

Merchan, F., de Lorenzo, L., Rizzo, S. G., Niebel, A., Manyani, H., Frugier, F., Sousa, C., and Crespi, M. 2007. Identification of regulatory pathways involved in the reacquisition of root growth after salt stress in Medicago truncatula. Plant J. 51:1-17.

Middleton, P. H., Jakab, J., Penmetsa, R. V., Starker, C. G., Doll, J., Kaló, P., Prabhu, R., Marsh, J. F., Mitra, R. M., Kereszt, A., Dudas, B., VandenBosch, K., Long, S. R., Cook, D. R., Kiss, G. B., and Oldroyd, G. E. D. 2007. An ERF transcription factor in Medicago truncatula that is essential for Nod factor signal transduction. Plant Cell 19:12211234.

Miller-Williams, M., Loewen, P. C., and Oresnik, I. J. 2006. Isolation of salt-sensitive mutants of Sinorhizobium meliloti strain Rm1021. Microbiology 152:2049-2059.

Mitra, R. M., Gleason, C. A., Edwards, A., Hadfield, J., Downie, J. A., Oldroyd, G. E. D., and Long, S. R. 2004a. A Ca ${ }^{2+} /$ calmodulin-dependent protein kinase required for symbiotic nodule development: Gene identification by transcript-based cloning. Proc. Natl. Acad. Sci. U.S.A. 101: 4701-4705.

Mitra, R. M., Shaw, S. L., and Long, S. R. 2004b. Six nonnodulating plant mutants defective for Nod factor-induced transcriptional changes associated with the legume-rhizobia symbiosis. Proc. Natl. Acad. Sci. U.S.A. 101:10217-10222.

Mortier, V., De Wever, E., Vuylsteke, M., Holsters, M., and Goormachtig, S. 2012. Nodule numbers are governed by interaction between CLE peptides and cytokinin signaling. Plant J. 70:367-376.

Mortier, V., Den Herder, G., Whitford, R., Van de Velde, W., Rombauts, S., D'haeseleer, K., Holsters, M., and Goormachtig, S. 2010. CLE peptides control Medicago truncatula nodulation locally and systemically. Plant Physiol. 153:222-237.

Murray, J. D. 2011. Invasion by invitation: Rhizobial infection in legumes. Mol. Plant-Microbe Interact. 24:631-639.

Murray, J. D., Karas, B. J., Sato, S., Tabata, S., Amyot, L., and Szczyglowski, K. 2007. A cytokinin perception mutant colonized by Rhizobium in the absence of nodule organogenesis. Science 315:101104.

Murray, J. D., Liu, C.-W., Chen, Y., and Miller, A. J. 2017. Nitrogen sensing in legumes. J. Exp. Bot. 68:1919-1926.

Nachshon, U. 2018. Cropland soil salinization and associated hydrology: Trends, processes and examples. Water 10:1030.

Noctor, G., Mhamdi, A., and Foyer, C. H. 2014. The roles of reactive oxygen metabolism in drought: Not so cut and dried. Plant Physiol. 164: 1636-1648.
Okamoto, M., Tatematsu, K., Matsui, A., Morosawa, T., Ishida, J., Tanaka, M., Endo, T. A., Mochizuki, Y., Toyoda, T., Kamiya, Y., Shinozaki, K., Nambara, E., and Seki, M. 2010. Genome-wide analysis of endogenous abscisic acid-mediated transcription in dry and imbibed seeds of Arabidopsis using tiling arrays. Plant J. 62:39-51.

Oldroyd, G. E. D. 2013. Speak, friend, and enter: Signalling systems that promote beneficial symbiotic associations in plants. Nat. Rev. Microbiol. 11:252-263.

Oldroyd, G. E. D., Engstrom, E. M., and Long, S. R. 2001. Ethylene inhibits the Nod factor signal transduction pathway of Medicago truncatula. Plant Cell 13:1835-1849.

Oldroyd, G. E. D., and Long, S. R. 2003. Identification and characterization of Nodulation-Signaling Pathway 2, a gene of Medicago truncatula involved in Nod factor signaling. Plant Physiol. 131:1027-1032.

Pan, H., Stonoha-Arther, C., and Wang, D. 2018. Medicago plants control nodulation by regulating proteolysis of the receptor-like kinase DMI2. Plant Physiol. 177:792-802.

Penmetsa, R. V., and Cook, D. R. 1997. A legume ethylene-insensitive mutant hyperinfected by its rhizobial symbiont. Science 275:527-530.

Penmetsa, R. V., Uribe, P., Anderson, J., Lichtenzveig, J., Gish, J.-C., Nam, Y. W., Engstrom, E., Xu, K., Sckisel, G., Pereira, M., Baek, J. M., Lopez-Meyer, M., Long, S. R., Harrison, M. J., Singh, K. B., Kiss, G. B., and Cook, D. R. 2008. The Medicago truncatula ortholog of Arabidopsis EIN2, sickle, is a negative regulator of symbiotic and pathogenic microbial associations. Plant J. 55:580-595.

Pérez-Montaño, F., del Cerro, P., Jiménez-Guerrero, I., López-Baena, F. J., Cubo, M. T., Hungria, M., Megías, M., and Ollero, F. J. 2016. RNA-seq analysis of the Rhizobium tropici CIAT 899 transcriptome shows similarities in the activation patterns of symbiotic genes in the presence of apigenin and salt. BMC Genomics 17:198.

Pimentel, D., Berger, B., Filiberto, D., Newton, M., Wolfe, B., Karabinakis, E., Clark, S., Poon, E., Abbett, E., and Nandagopal, S. 2004. Water resources: Agricultural and environmental issues. Bioscience 54:909918.

R Core Team. 2013. R: A Language and Environment for Statistical Computing. R Foundation for Statistical Computing, Vienna, Austria. https:// www.r-project.org/

Reid, D., Nadzieja, M., Novák, O., Heckmann, A. B., Sandal, N., and Stougaard, J. 2017. Cytokinin biosynthesis promotes cortical cell responses during nodule development. Plant Physiol. 175:361-375.

Rinaudi, L., Fujishige, N. A., Hirsch, A. M., Banchio, E., Zorreguieta, A., and Giordano, W. 2006. Effects of nutritional and environmental conditions on Sinorhizobium meliloti biofilm formation. Res. Microbiol. 157: 867-875.

Rival, P., de Billy, F., Bono, J.-J., Gough, C., Rosenberg, C., and Bensmihen, S. 2012. Epidermal and cortical roles of NFP and DMI3 in coordinating early steps of nodulation in Medicago truncatula. Development 139:3383-3391.

Roy, S., Liu, W., Nandety, R. S., Crook, A. D., Mysore, K. S., Pislariu, C. I., Frugoli, J. A., Dickstein, R., and Udvardi, M. K. 2020. Celebrating 20 years of genetic discoveries in legume nodulation and symbiotic nitrogen fixation. Plant Cell 32:15-41.

Rüberg, S., Tian, Z. X., Krol, E., Linke, B., Meyer, F., Wang, Y., Pühler, A., Weidner, S., and Becker, A. 2003. Construction and validation of a Sinorhizobium meliloti whole genome DNA microarray: Genomewide profiling of osmoadaptive gene expression. J. Biotechnol. 106: 255-268.

Sańko-Sawczenko, I., Łotocka, B., Mielecki, J., Rekosz-Burlaga, H., and Czarnocka, W. 2019. Transcriptomic changes in Medicago truncatula and lotus japonicus root nodules during drought stress. Int. J. Mol. Sci. 20:1204.

Schiessl, K., Lilley, J. L. S., Lee, T., Tamvakis, I., Kohlen, W., Bailey, P. C., Thomas, A., Luptak, J., Ramakrishnan, K., Carpenter, M. D., Mysore, K. S., Wen, J., Ahnert, S., Grieneisen, V. A., and Oldroyd, G. E. D. 2019. NODULE INCEPTION recruits the lateral root developmental program for symbiotic nodule organogenesis in Medicago truncatula. Curr. Biol. 29:3657-3668.e5.

Shaar-Moshe, L., Blumwald, E., and Peleg, Z. 2017. Unique physiological and transcriptional shifts under combinations of salinity, drought, and heat. Plant Physiol. 174:421-434.

Sherwood, S., and Fu, Q. 2014. A drier future? Science 343:737-739.

Shin, R., Berg, R. H., and Schachtman, D. P. 2005. Reactive oxygen species and root hairs in Arabidopsis root response to nitrogen, phosphorus and potassium deficiency. Plant Cell Physiol. 46:1350-1357.

Šimura, J., Antoniadi, I., Široká, J., Tarkowská, D., Strnad, M., Ljung, K., and Novák, O. 2018. Plant hormonomics: Multiple phytohormone profiling by targeted metabolomics. Plant Physiol. 177:476-489. 
Singleton, P. W., and Bohlool, B. B. 1984. Effect of salinity on nodule formation by soybean. Plant Physiol. 74:72-76.

Sinharoy, S., Liu, C., Breakspear, A., Guan, D., Shailes, S., Nakashima, J., Zhang, S., Wen, J., Torres-Jerez, I., Oldroyd, G., Murray, J. D., and Udvardi, M. K. 2016. A Medicago truncatula cystathionine- $\beta$-synthase-like domain-containing protein Is required for rhizobial infection and symbiotic nitrogen fixation. Plant Physiol. 170:2204-2217.

Smit, P., Raedts, J., Portyanko, V., Debellé, F., Gough, C., Bisseling, T., and Geurts, R. 2005. NSP1 of the GRAS protein family is essential for rhizobial Nod factor-induced transcription. Science 308:1789-1791.

Song, J., Mo, X., Yang, H., Yue, L., Song, J., and Mo, B. 2017. The U-box family genes in Medicago truncatula: Key elements in response to salt, cold, and drought stresses. PLoS One 12:e182402.

Soumaya, A., Mounawer, B., Wael, T., Thierry, H., and Mohamed, E. A. 2011. Variability salt stress response analysis of Tunisian natural populations of Medicago truncatula (Fabaceae) using salt response index (SRI) ratio. Afr. J. Biotechnol. 10:10636-10647.

Soussi, M., Ocaña, A., and Lluch, C. 1998. Effects of salt stress on growth, photosynthesis and nitrogen fixation in chick-pea (Cicer arietinum L.). J. Exp. Bot. 49:1329-1337.

Soyano, T., Shimoda, Y., Kawaguchi, M., and Hayashi, M. 2019. A shared gene drives lateral root development and root nodule symbiosis pathways in Lotus. Science 366:1021-1023.

Stanton-Geddes, J., Paape, T., Epstein, B., Briskine, R., Yoder, J., Mudge, J., Bharti, A. K., Farmer, A. D., Zhou, P., Denny, R., May, G. D., Erlandson, S., Yakub, M., Sugawara, M., Sadowsky, M. J., Young, N. D., and Tiffin, P. 2013. Candidate genes and genetic architecture of symbiotic and agronomic traits revealed by whole-genome, sequencebased association genetics in Medicago truncatula. PLoS One 8:e65688.

St.Clair, S. B., and Lynch, J. P. 2010. The opening of Pandora's Box: Climate change impacts on soil fertility and crop nutrition in developing countries. Plant Soil 335:101-115.

Sutherland, I. W. 1997. Microbial exopolysaccharides-Structural subtleties and their consequences. Pure Appl. Chem. 69:1911-1917.

Suzuki, A., Akune, M., Kogiso, M., Imagama, Y., Osuki, K. I., Uchiumi, T., Higashi, S., Han, S. Y., Yoshida, S., Asami, T., and Abe, M. 2004. Control of nodule number by the phytohormone abscisic acid in the roots of two leguminous species. Plant Cell Physiol. 45:914-922.

Tal, I., Zhang, Y., Jørgensen, M. E., Pisanty, O., Barbosa, I. C. R., Zourelidou, M., Regnault, T., Crocoll, C., Erik Olsen, C., Weinstain, R., Schwechheimer, C., Halkier, B. A., Nour-Eldin, H. H., Estelle, M., and Shani, E. 2016. The Arabidopsis NPF3 protein is a GA transporter. Nat. Commun. 7:11486.

Tester, M. 2003. $\mathrm{Na}^{+}$tolerance and $\mathrm{Na}^{+}$transport in higher plants. Ann. Bot. 91:503-527.

Tirichine, L., Sandal, N., Madsen, L. H., Radutoiu, S., Albrektsen, A. S., Sato, S., Asamizu, E., Tabata, S., and Stougaard, J. 2007. A gain-offunction mutation in a cytokinin receptor triggers spontaneous root nodule organogenesis. Science 315:104-107.

Trinchant, J.-C. C., Boscari, A., Spennato, G., Van de Sype, G., and Le Rudulier, D. 2004. Proline betaine accumulation and metabolism in alfalfa plants under sodium chloride stress. Exploring its compartmentalization in nodules. Plant Physiol. 135:1583-1594.

Tu, J. C. 1981. Effect of salinity on Rhizobium-root hair interaction, nodulation and growth of soybean. Can. J. Plant Sci. 61:231-239.

van Zeijl, A., Liu, W., Xiao, T. T., Kohlen, W., Yang, W. C., Bisseling, T., and Geurts, R. 2015a. The strigolactone biosynthesis gene DWARF27 is co-opted in rhizobium symbiosis. BMC Plant Biol. 15:260.

van Zeijl, A., Op den Camp, R. H. M., Deinum, E. E., Charnikhova, T., Franssen, H., Op den Camp, H. J. M., Bouwmeester, H., Kohlen, W., Bisseling, T., and Geurts, R. 2015b. Rhizobium lipo-chitooligosaccharide signaling triggers accumulation of cytokinins in Medicago truncatula roots. Mol. Plant 8:1213-1226.

Verbruggen, N., and Hermans, C. 2008. Proline accumulation in plants: A review. Amino Acids 35:753-759.
Vernié, T., Kim, J., Frances, L., Ding, Y., Sun, J., Guan, D., Niebel, A., Gifford, M. L., de Carvalho-Niebel, F., and Oldroyd, G. E. D. 2015. The NIN transcription factor coordinates diverse nodulation programs in different tissues of the Medicago truncatula root. Plant Cell 27:3410-3424.

Verslues, P. E. 2017. Time to grow: Factors that control plant growth during mild to moderate drought stress. Plant Cell Environ. 40:177-179.

Walker-Simmons, M. 1987. ABA levels and sensitivity in developing wheat embryos of sprouting resistant and susceptible cultivars. Plant Physiol. 84:61-66.

Wang, C., Yu, H., Luo, L., Duan, L., Cai, L., He, X., Wen, J., Mysore, K. S., Li, G., Xiao, A., Duanmu, D., Cao, Y., Hong, Z., and Zhang, Z. 2016. NODULES WITH ACTIVATED DEFENSE 1 is required for maintenance of rhizobial endosymbiosis in Medicago truncatula. New Phytol. 212: 176-191.

Wang, H., Jiang, H., Xu, Y., Wang, Y., Zhu, L., Yu, X., Kong, F., Zhou, C., and Han, L. 2020. Systematic analysis of gibberellin pathway components in Medicago truncatula reveals the potential application of gibberellin in biomass improvement. Int. J. Mol. Sci. 21:7180.

Wu, H., Zhang, X., Giraldo, J. P., and Shabala, S. 2018. It is not all about sodium: Revealing tissue specificity and signalling roles of potassium in plant responses to salt stress. Plant Soil 431:1-17.

Xie, F., Murray, J. D., Kim, J., Heckmann, A. B., Edwards, A., Oldroyd, G. E. D., and Downie, J. A. 2012. Legume pectate lyase required for root infection by rhizobia. Proc. Natl. Acad. Sci. U.S.A. 109:633-638.

Xie, J., Tian, J., Du, Q., Chen, J., Li, Y., Yang, X., Li, B., and Zhang, D. 2016. Association genetics and transcriptome analysis reveal a gibberellin-responsive pathway involved in regulating photosynthesis. J. Exp. Bot. 67:3325-3338.

Xu, K., Chen, S., Li, T., Ma, X., Liang, X., Ding, X., Liu, H., and Luo, L. 2015. OsGRAS23, a rice GRAS transcription factor gene, is involved in drought stress response through regulating expression of stressresponsive genes. BMC Plant Biol. 15:141.

Yang, C., Liu, J., Dong, X., Cai, Z., Tian, W., and Wang, X. 2014. Shortterm and continuing stresses differentially interplay with multiple hormones to regulate plant survival and growth. Mol. Plant 7:841-855.

Yang, C., Signer, E. R., and Hirsch, A. 1992. Nodules initiated by Rhizobium meliloti exopolysaccharide mutants lack a discrete, persistent nodule meristem. Plant Physiol. 98:143-151.

Yoder, J. B., Stanton-Geddes, J., Zhou, P., Briskine, R., Young, N. D., and Tiffin, P. 2014. Genomic signature of adaptation to climate in Medicago truncatula. Genetics 196:1263-1275.

Zahaf, O., Blanchet, S., de Zélicourt, A., Alunni, B., Plet, J., Laffont, C., De Lorenzo, L., Imbeaud, S., Ichanté, J. L., Diet, A., Badri, M., Zabalza, A., González, E. M., Delacroix, H., Gruber, V., Frugier, F., and Crespi, M. 2012. Comparative transcriptomic analysis of salt adaptation in roots of contrasting Medicago truncatula genotypes. Mol. Plant 5:1068-1081.

Zahran, H. H. 1999. Rhizobium-legume symbiosis and nitrogen fixation under severe conditions and in an arid climate. Microbiol. Mol. Biol. Rev. 63:968-989.

Zahran, H. H., and Sprent, J. I. 1986. Effects of sodium chloride and polyethylene glycol on root-hair infection and nodulation of Vicia faba L. plants by Rhizobium leguminosarum. Planta 167:303-309.

Zhang, H., Cao, Y., Shang, C., Li, J., Wang, J., Wu, Z., Ma, L., Qi, T., Fu, C., Bai, Z., and Hu, B. 2017. Genome-wide characterization of GRAS family genes in Medicago truncatula reveals their evolutionary dynamics and functional diversification. PLoS One 12:e0185439.

Zhang, L.-Y., Cai, J., Li, R.-J., Liu, W., Wagner, C., Wong, K.-B., Xie, Z.-P., and Staehelin, C. 2016. A single amino acid substitution in a chitinase of the legume Medicago truncatula is sufficient to gain Nod-factor hydrolase activity. Open Biol. 6:160061.

Zhang, M., Smith, J. A. C., Harberd, N. P., and Jiang, C. 2016. The regulatory roles of ethylene and reactive oxygen species (ROS) in plant salt stress responses. Plant Mol. Biol. 91:651-659.

Zipfel, C., and Oldroyd, G. E. D. 2017. Plant signalling in symbiosis and immunity. Nature 543:328-336. 